$1-1-1959$

\title{
Milk Vending : A Market-Wide Evaluation in Berkeley County, West Virginia
}

James H. Clarke

Mardy Myers

J.Scott Hunter

Follow this and additional works at: https://researchrepository.wvu.edu/ wv_agricultural_and_forestry_experiment_station_bulletins

\section{Digital Commons Citation}

Clarke, James H.; Myers, Mardy; and Hunter, J. Scott, "Milk Vending : A Market-Wide Evaluation in Berkeley County, West Virginia" (1959). West Virginia Agricultural and Forestry Experiment Station Bulletins. 429.

https://researchrepository.wvu.edu/wv_agricultural_and_forestry_experiment_station_bulletins/407 




\section{MILK VENDING =-}

A Market-Wide Evaluation in Berkeley County, W. Va.

A joint publication of the West Virginia Agricultural Experiment Station and the Marketing Research Division, Agricultura! Marketing Service United States Department of Agriculture

Bulletin 429, June 1959

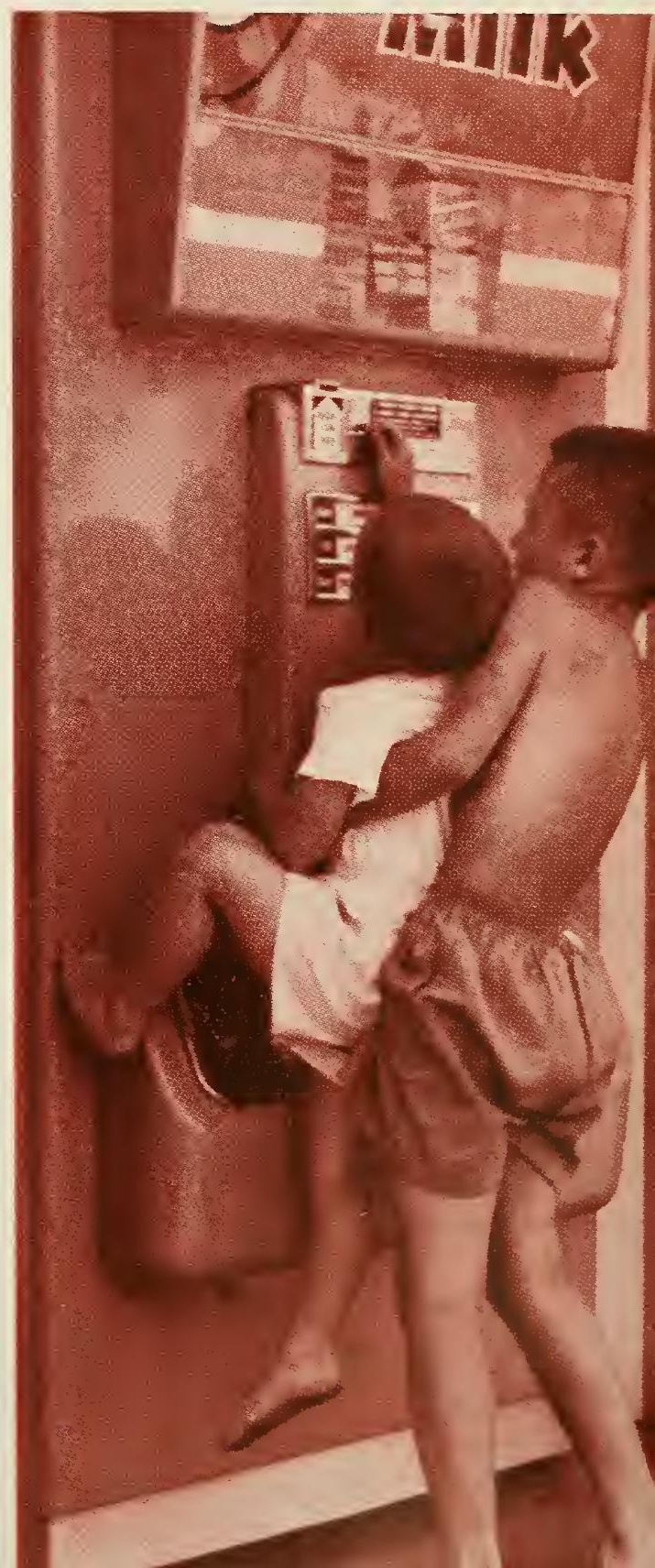


Digitized by the Internet Archive in 2010 with funding from

Lyrasis Members and Sloan Foundation 


\section{MILK VENDING--}

A Market-Wide Evaluation in Berkeley County, W. Va.

James H. Clarke, Mardy Myers

and $J$. Scott Hunter 


\section{THE AUTHORS}

James H. Clarke is Associate Agricultural Economist in the West Virginia University Agricultural Experiment Station; Mardy Myers is Agricultural Economist, Agricultural Marketing Service, USDA; and J. Scott Hunter is Social Science Analyst, Agricultural Marketing Service, USDA.

The research reported in this publication was conducted cooperatively by the Agricultural Experiment Station, West Virginia University, and the Market Development Branch, Agricultural Marketing Service, United States Department of Agriculture.

It is a contribution to the Northeast Dairy Merchandising Technical Committee's research project NEM-14: Merchandising Milk and Other Dairy Products.

WEST Virginia UNIVERSITY

Agricultural Experment Station

College of Agriculture, Forestry, and Home Economics

A. H. Vanlandingham, Director

MORGANTOWN 


\section{Contents}

SUMMARY

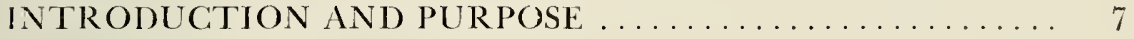

TRENDS IN VENDING .................... 7

TRENIOS IN UTILIZATION OF MILK ............. 8

CHARACTERISTICS OF THE TEST AREA ........... 9

TEST METHODS . ..................... 10

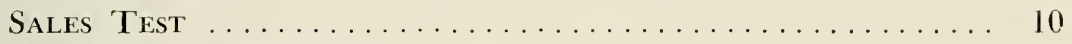

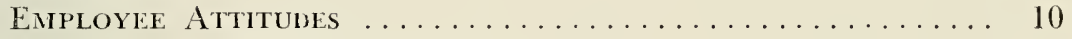

Linitations of the Data $\ldots \ldots \ldots \ldots \ldots \ldots \ldots \ldots \ldots \ldots \ldots$

TEST RESULTS ........................ 11

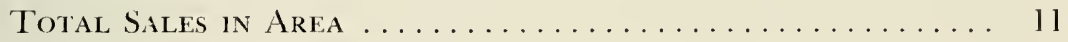

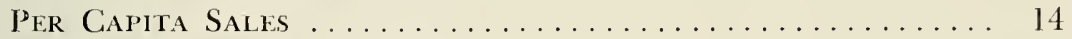

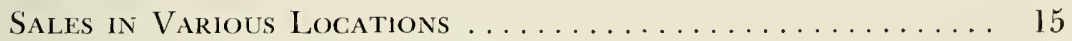

Industrial Plants and Offices ............... 15

Schools ............................. 17

Maximum Use Tests in Schools ................31

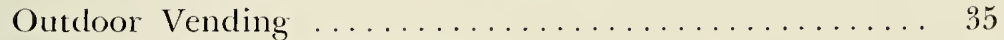

Preferences for Pkonucts Vended ................. 37

Industrial Plants and Offices ................ 37

Schools .......................... 38

Milk Compared with Competing Products ......... 38

EMPLOYEES' ATTITUDES TOWARD MILK VENDING

MACHINES ........................ 39

Survey Results ... . . . . . . . . . . . . . . . . . . . 39

Employees Use of Milk Vending Machines ... . . . . . . . . 39

Competition from Other Beverage Vending Machines . . . . 43

Employee Dissatisfactions with Milk Vending Machines ... 44

MANAGEMENT REACTIONS TO MLK VENDING

MACHINES ...................... 46

ESTIMATING COSTS AND RETURNS ............. 46

OBSTACLES TO MILK VENDING .............. 48

NET EFFECT OF VENDING ................ 50

APPENDIX ........................... 51

Technigal Notes on Employee Survey .............. 5I

Appendix Tables ....................... 52 


\section{Acknowledgements}

The authors gratefully acknowledge the cooperation and assistance given them by the milk distributors, their employees, and vending operators in the Berkeley County area. Without their help this study would not have been possible. School principals and personnel of the office of the Berkeley County School Superintendent also provided essential information. Owners and managers of the plants and offices where milk vending was tested also made valuable contributions to this study. Especially helpful were: James L. Creasy, Superintendent, Berkeley County schools; James Dillon and David Malone, Shepherd Beverage Service; Joseph W. Haas, Interwoven Stocking Company; Fred Hammond, Superior Dairy, Casper E. Kight, Jr., and Chester Ranker, Berkeley Farmers Dairy; Francis L. Patton, Loudoun Distributing Company, Incorporated; and E. N. Thatcher, Thatcher's Dairy.

The authors are also indebted to their colleagues in both the West Virginia University Agricultural Experiment Station and the United States Department of Agriculture for valuable counsel and guidance during the course of the study. Especial credit is due Philip B. Dowskin, of the United States Department of Agriculture, and Walter F. Thompson, formerly of the United States Department of Agriculture, for their assistance in the planning and early operational phases of the study.

Cooperation and counsel were also furnished by representatives of the following vending machine manufacturers: The Ideal Dispenser Company; the Pure-Pak Division, Excello Corporation; The Rowe Manufacturing Company, Incorporated; and The Vendo Corporation. 


\section{Summary}

ALES of fluid milk through coin-operated vending machines averaged 1.5 per cent of total milk sales in the Berkeley County, IVest Virginia, market area during the period from October 1955 to June 1957. Total milk sales, population, and personal incomes showed a slight upward trend during this period. More than 70 percent of the milk vended was sold through machines in plants and offices. The proportion of employees using milk in the plants and offices where milk vending machines were installed increased from 19 percent before the installation to 63 percent after the installation. Total sales of milk in five schools studied increased 26 percent after the introduction of milk vending, whereas school attendance increased only 7 percent. More than half of the milk sold through the vending machines in all locations appears to have been a net increase in total sales.

These findings were obtained from observations made over a 22 month period. The attempt to install the maximum number of machines economically feasible in plants and offices in the area was largely successful. Machines were also placed in five schools and three outdoor locations.

In general, sales through the vending machines declined after the first few months of operation. Sales volumes per machine varied widely depending on location and other factors.

Those using the milk vending machines preferred chocolate milk* or drink to the other milk products vended. In plant and office locations offering chocolate milk or drink and homogenized milk, the ratio was 2.4 chocolate to 1.0 homogenized. When the machines offered chocolate, orange drink, and homogenized, the ratios were 2.3 chocolate, 0.8 orange, and 1.0 homogenized. When chocolate milk or drink, buttermilk, and homogenized milk were offered, the ratios were 2.6 chocolate, 0.3 buttermilk, and 1.0 homogenized.

Greater vending speed was possible with fully automatic machines. This extra speed was needed where rest or recess periods were short and where there was a comparatively large number of potential customers.

In the Berkeley County, West Virginia area, consumers' sales taxes and soft-drink taxes on chocolate milk or drink and on orange drink were part of variable costs. Hence, the gross margin from sales of onehalf pints of milk through vending machines were low, ranging from

* Chocolaie nilk in West Virginia was a chocolate flavored milk with more than 3 percent butterfat. Chocolate drink was a chocolate flavored milk product containing less than 3 percent butterfat. (Legislation enacted by the State Legislature in its 1959 Session rules that chocolate milk is a chocolate flavored drink with 3.5 or more percent butteriat; and that chorolate drink is a chocolate flavored milk containing less than 3.5 percent butterfat.) 
0.5 cents to 1.5 cents. With gross margins of this size, large volumes are necessary to meet the fixed costs incident to milk vending. In areas where gross margins are larger, fewer sales per machine would be needed to break even.

A number of machines operated in low-volume locations during the course of the study and were discontinued within one year following its termination. There was no indication that milk sales through vending machines would rise during an extended period of vending unless the number of potential patrons increased or other conditions surrounding the vending were changed. It may be concluded that if vending machines do not break even in the first few months of operation they are not apt to later on.

Adverse attitudes toward milk vending machines, as such, or toward inconveniences associated with merchandising milk by this means did not appear to be limiting factors in the use of these machines. Most of the managers of plants using milk vending machines commented favorably about their experiences with milk vending.

Obstacles to milk vending observed in this study were taxes in the product, licenses, initial attitudes of plant managers and school officials, opposition to chocolate milk or drink in schools, competitive relationships, and mechanical difficulties. However, none of these obstacles was serious enough to prevent satisfactory milk vending operations. 


\section{MILK VENDING - - A Market-Wide Evaluation in Berkeley County, W. Va.}

\section{Introduction and Purpose}

means of expanding consumption of milk or any product is to make it more available. Locating vending machines where milk is not usually available is one means of improving availability. These locations can be offices, factories, apartments, filling stations, schools, recreation centers, shopping centers, and other places where large groups of people congregate, and where milk is not readily available. In many locations, some of these vending machines can also serve as media for milk distribution during the evening and on weekends and holidays, when most other means of milk distribution are reduced in number.

The purpose of this marketing research project was not to test the hypothesis that milk can be sold successfully through vending machines. This already has been demonstrated. The study was made to measure the effect of such sales on total sales of milk in all the channels of a market. Furthermore, this study was conducted over a relatively long period of time in order to observe seasonal and innovational effects.

An important part of this study was to find out about consumer use of milk vending machines and consumers' likes and dislikes for this type of distribution for milk.

Closely associated with this study was research into the relative costs of distributing milk through vending machines and by means of retail and wholesale rontes in and around Martinsburg, West Virginia. The amounts of labor and other cost factors required for vending were determined and the break-even points found for various kinds of vending routes. Detailed findings on the cost phase of the study are available in United States Department of Agriculture Marketing Research Report No. 229, Costs of Distributing Milk Through Vending Machines and by Retail and Wholesale Routes, by Jack E. Klein, published in May 1958.

\section{Trends in Vending}

The greatest expansion in selling milk through vending machines has come since 1946. Prior to that time, vending machines were used 
generally to vend cigarettes, candy, and bottled beverages. However, with the improvement in electronic devices during World War II, new and improved machines were developed to dispense such products as milk, hot coffee, fruit juices, and many other food and nonfood items. Added emphasis to this development of vending in the post-war period resulted from a growing interest in automatic merchandising as a means of making products more readily available and also as a means of reducing marketing costs.

It was estimated by Vend Magazine that there were approximately 16,000 milk vending machines in indoor locations in 1954, doing an estimated $\$ 22$ million in sales annually. The number of machines increased to 21,000 in $1955,27,500$ in $1956,36,400$ in 1957 , and 41,750 in 1958. The machines on location in 1957 sold about 500 million units, with dollar sales approximately $\$ 50$ million. Most of the machines at indoor locations vend one-half pints, although one-third quarts and pints are not uncommon. Assuning the vending unit averaged 0.6 pound of milk, about 300 million pounds of milk would have been sold through indoor vending machines in 1957. Only scattered data exist on sales of milk through outdoor vending machines selling mostly quarts and one-half gallons.

Recently published data by Vend Magazine show that milk vending declined in 1958 in both total unit sales and total dollar volume. For example, milk vending machines on location in 1958 sold an average of 220 units of milk weekly; in 1957 the figure was 275; and in 1956 it was 300 units. Thus there was a drop of 80 units per machine in two years time.

\section{Trends in Utilization of Milk}

Milk consumed per capita in all forms-fluid and processed-has failed to keep pace with milk production per capita during the postwar period. This has been associated with the declining demand for butterfat, especially in the form of butter. However, per capita consumption of fluid whole milk has trended upward in the past 10 years, although the 308-pounds-per-person U. S. average for 1956 was still below the high levels established during the World War II years. This slight upward trend in use of whole milk over the past ten years has occurred despite significant price increases at retail and even slight declines in per capita income in one or two years. However, the response of fluid milk use to changes in income and price usually is less pronounced than the response of most other agricultural commodities.

The failure of total milk consumption in all forms to keep pace with total milk production has resulted in large purchases of butter, 
cheese, and nonfat dry milk under the Price Support Program. Milk equivalent purchases of butter and cheese totaled 5.2 billion pounds in 1956 and 5.9 billion pounds in 1957, or about 5 percent of total output.

\section{Characteristics of Test Area}

The test area for this marketing research was Berkeley County, West Virginia, in the Eastern Panhandle of the State. The area has a population of about 32,000. Martinsburg is the county seat and was the location of most of the machines observed through the experimental period. Per capita income was about 20 percent below the national average but just above the average for the State. It is a rather stable marketing area and there is little in or out movement in terms of retail trade. The principal industries in the area are apple processing, hospitals (including a veteran's hospital), textiles, explosives, limestone quarries, furniture, veneer, and other small manufacturing units.

At the time of the study, there were in the area three milk distributors with processing plants and/or distributing points; in addition, a distributor located in Leesburg, Virginia, had one route in the Berkeley County area. Consumption of dairy products in this area was below the national average. Prices for milk and dairy products were not out of line with those in contiguous areas.

\section{Test Methods}

\section{SALES TEST}

Sales data were obtained for each machine on location during the 22-month period from September 1955, to June 1957. These data were maintained by the operator on a daily basis. In addition, monthly sales data were obtained on sales through all other outlets in this area for the period from October 1954, through June 1957.

Immediately prior to September 1955, there were no milk vending machines in the Berkeley County area, although a few had been used several years earlier. The sales test was started in October 1955, when machines were installed in seven locations. Two other machines had been installed during the preceding month. The number of machines was increased gradually as opportunities to locate them developed. Ultimately machines were placed in 19 locations in industrial plants and offices, five locations in schools, and three outdoor locations. The observation period continued through June 1957; however, the number of machines on location was not constant primarily because of seasonal factors. 
In order to insure continuity and to keep dislocations at a minimum, vending machine operators were paid rental fees by the West Virginia Agricultural Experiment Station on the condition that they would keep the machines in the specified locations and would supply detailed records of sales through the machines and of total sales throughout the test period. Rental fees were based on a formula which resulted in a lower rental fee as sales increased. In turn, the operators of the vending machines paid one cent per one-half pint ( 10 percent of the selling price) for the privilege of using the space occupied by the milk vending machine and for electric current and other services provided for the machine by the location owner. In some cases these payments were made to welfare funds rather than to the owner. Such payments were not made at schools where milk prices were reduced as a result of the Special Milk Program subsidy.

An attempt was made to place as many milk vending machines in locations in plants and offices as appeared economically feasible. This was achieved for all except two plants among those which seemed to have sufficient workers to justify an installation. However, enough machines were placed in plants with fewer employees to offset this omission. Milk vending was limited some what in schools because it was believed that vended milk would merely replace milk provided under the Special Milk Program. Nor was an attempt made to introduce milk to the Veteran's hospital because adequate milk was already being supplied in that institution. The number of machines placed in outdoor locations was limited by competitive relationships which will be described later in the report.

\section{EMPLOYEE ATTITUDES}

The data on which the employee-attitude phase of the study is based were obtained by personal interviews in 12 of the industrial plants where milk vending machines were located. In each plant a systematic sample was drawn from lists of employees. The sampling rate was two in five in 11 of the plants and one in ten in the twelfth plant, which was much larger than the rest. Data from this plant were weighted by four so that their representation in the sample would be equal to their proportion of all the employees sampled.

Most of the interviewing was done at the respondents' place of work, but in instances where this was not possible the interviews were conducted in the respondents' homes. The survey was made during the first three weeks of May 1957, and interviews were completed with 432 respondents.

In addition to interviews with employees, a brief interview also was conducted with the manager of each plant or with his representatives, 
in order to obtain his reactions to the use of vending machines in the plant.

\section{LIMITATIONS OF DATA}

Actual records on vending machine sales were maintained by cooperating dairies and vending machine operators. In addition, monthly sales data of retail and wholesale routes were obtained from records of cooperating dairies. Thus, a complete record of all milk sales was obtained. Independent checks of sales were established by comparison with bottling data, where possible. Call-backs were made in all cases where the data seemed to be of questionable validity.

The consumer attitude survey was made on a sampling basis. The method for estimating sampling variability may be found in page 51 .

\section{Test Results}

\section{TOTAL SALES IN AREA}

Both total and vended milk sales in Berkeley County are shown in Table 1. Total sales of milk per month from October 1954, to June 1957, ranged from 55,910 gallons to 71,601 gallons and showed a slight upward trend as the study progressect (Figure 1). Part of this increase may be attributed to the estimated growth in population (Table 2). Personal income in Berkeley County and consumers' sales tax collections also rose during the period, as indicated below:

$\begin{array}{ccc}\text { YEAR } & \begin{array}{c}\text { PERSONAL } \\ \text { INCOME* }\end{array} & \begin{array}{c}\text { CONSUMERS' SALES TAX } \\ \text { COLLECTIONS ** }\end{array} \\ 1954 & \text { Million dollars } & \text { Thousand dollars } \\ 1955 & 45.2 & 462.2 \\ 1956 & 48.9 & 497.9 \\ 1957 & 53.5 & 522.3 \\ & 51.8 & 547.7 \dagger\end{array}$

*West Virginia Chamber of Commerce, Personal Income and Retail Sales in West Virginia by Counties, 1957, Charleston, W. Va., May 1958, p. 2.

**Letter, June 19, 1958, from Earle L. Elmore, Research Director, West Virginia Chamber of Commerce, Charleston, W. Va.

$\dagger$ Monthly data indicate that more than the usual collections made in December the preceding year were reported early in 1957.

Another factor may have increased total milk sales during this period. In October 1955, at approximately the same time that milk vending began, some distributors introduced one-half gallon cartons of homogenized milk into the market area. These one-half gallon cartons were priced at one-half cent per quart less than single quarts of homogenized milk in paper cartons. Prices for all other products remained unchanged throughout the period of study. 
Table 1. Total Milk Sold Monthly and Daily, Total Milk Vended, and Proportion of Milk Vended, Berkeley County, West Virginia, OCTOBER 1954, to JUNE 1957

\begin{tabular}{|c|c|c|c|c|}
\hline \multirow{2}{*}{$\begin{array}{l}\text { YEAR } \\
\text { AND } \\
\text { MONTH }\end{array}$} & \multicolumn{2}{|c|}{ TOTAL MILK SOLD } & \multirow{2}{*}{$\begin{array}{l}\text { TOtal Milk } \\
\text { VENDED } \\
\text { PER MONTH }\end{array}$} & \multirow{2}{*}{$\begin{array}{c}\text { Proportion } \\
\text { MuLK } \\
\text { VENDED }\end{array}$} \\
\hline & PER Month* & PER DAY* & & \\
\hline \multicolumn{5}{|r|}{ Percent } \\
\hline $\begin{array}{l}1954 \\
\text { Oct. }\end{array}$ & 60,348 & 1,947 & $* *$ & $* *$ \\
\hline Nov. & 58,829 & 1,961 & $* *$ & $* *$ \\
\hline Dec. & 59,039 & 1,904 & $* *$ & $* *$ \\
\hline \multicolumn{5}{|l|}{1955} \\
\hline Jan. & 60,592 & 1,955 & $\% *$ & $* *$ \\
\hline Feb. & 55,941 & 1,998 & $* *$ & $* *$ \\
\hline Mar. & 60,670 & 1,957 & $* *$ & ** \\
\hline Apr. & 61,305 & 2,044 & $* *$ & $* *$ \\
\hline May & 60,943 & 1,966 & ** & ** \\
\hline June & 56,901 & 1,897 & $* *$ & $* *$ \\
\hline July & 55,910 & 1,804 & $* *$ & $* *$ \\
\hline Aug. & 58,995 & 1,903 & ** & ** \\
\hline Sept. & 62,043 & 2,068 & $76 \div$ & 0.12 \\
\hline Oet. & 65,424 & 2,110 & 397 & 0.61 \\
\hline Nov. & 64,886 & 2,163 & 615 & 0.95 \\
\hline Dec. & 62,525 & 2,017 & 305 & 0.49 \\
\hline \multicolumn{5}{|l|}{1956} \\
\hline Jan. & 63.715 & 2,055 & 272 & 0.43 \\
\hline Feb. & 62,692 & 2,162 & 673 & 1.07 \\
\hline Mar. & 66,729 & 2,153 & 676 & 1.01 \\
\hline Apr. & 63,376 & 2,113 & 886 & 1.40 \\
\hline May & 63,506 & 2,049 & 1,301 & 2.05 \\
\hline June & 61,568 & 2,052 & 1,064 & 1.73 \\
\hline July & 63,068 & 2,034 & 1,099 & 1.74 \\
\hline Aug. & 65,171 & 2,102 & 1,256 & 1.93 \\
\hline Sept. & 67,008 & 2,234 & 1,598 & 2.38 \\
\hline Oct. & 71,601 & 2,310 & 1,776 & 2.48 \\
\hline Nov. & 66,829 & 2,228 & 1,247 & 1.87 \\
\hline Dec. & 66,641 & 2,150 & 1,031 & 1.55 \\
\hline \multicolumn{5}{|l|}{1957} \\
\hline $\begin{array}{l}\text { Jan. } \\
\text { Feb. }\end{array}$ & $\begin{array}{l}70,241 \\
63,543\end{array}$ & $\begin{array}{l}2,266 \\
2,269\end{array}$ & $\begin{array}{l}1,163 \\
1,046\end{array}$ & $\begin{array}{l}1.66 \\
1.65\end{array}$ \\
\hline $\begin{array}{l}\text { Feb. } \\
\text { Mar. }\end{array}$ & 68,665 & 2,215 & 1,005 & 1.46 \\
\hline Apr. & 68,058 & 2,269 & 1,108 & 1.63 \\
\hline May & 66,356 & $2,1+1$ & 1,118 & 1.68 \\
\hline June & 59,582 & 1,986 & 1,001 & 1.68 \\
\hline \multicolumn{5}{|c|}{ Total Oet. 1955} \\
\hline & $\begin{array}{l}\text { ne } 1957: \\
1,183=\end{array}$ & $2,146 \ddagger$ & 20,637 & 1.50 \\
\hline
\end{tabular}
County.

*Total milk sold includes all fresh fluid milk sales made by milk distributors in the

**None vended during this perlod.

$\dagger$ The first two machines were placed in plants on September 12, 1955.

Unweighted average.

As more milk vending machines were introduced into the market, the amount of milk vended showed an upward trend until October 1956. At this point, 2.48 percent of the sales in the market were made through vending machines. However, machines at seasonally operated 
Table 2. Dally Average Sales of Milk and Esthuated Per Ciapita Sales, Berkeley County, West Virginia, October 1954, to June 1957

\begin{tabular}{|c|c|c|c|c|c|}
\hline \multirow{2}{*}{$\begin{array}{c}\text { YEAR } \\
\text { AND } \\
\text { MONTH }\end{array}$} & \multicolumn{2}{|c|}{ DaIly Average Sales* } & \multicolumn{2}{|c|}{ Total Per Captta Sales } & \multirow[b]{2}{*}{$\begin{array}{l}\text { ESTIMATED } \\
\text { POPULATION** }\end{array}$} \\
\hline & $\begin{array}{c}\text { TOTAL } \\
\text { INCLUDING } \\
\text { VENDING }\end{array}$ & $\begin{array}{l}\text { VENDING } \\
\text { ONLY }\end{array}$ & $\begin{array}{c}\text { TOTAL } \\
\text { INCLUDING } \\
\text { VENDING }\end{array}$ & $\begin{array}{l}\text { VENDING } \\
\text { ONLY }\end{array}$ & \\
\hline $\begin{array}{l}1954 \\
\text { Oct. } \\
\text { Nov. } \\
\text { Dec. }\end{array}$ & $\begin{array}{l}\text { Pounds } \\
\begin{array}{l}16,744 \\
16,864 \\
16,374\end{array}\end{array}$ & $\begin{array}{l}\text { Pounds } \\
\qquad \begin{array}{c}\doteqdot \\
\doteqdot \\
\doteqdot\end{array}\end{array}$ & $\begin{array}{c}\text { Pounds } \\
\qquad \begin{array}{c}0.53 \\
.53 \\
.51\end{array}\end{array}$ & $\begin{array}{c}\text { Pounds } \\
\qquad \begin{array}{c}\dagger \\
\dagger \\
\dagger\end{array}\end{array}$ & $\begin{array}{l}\text { Number } \\
31,818 \\
31,846 \\
31,875\end{array}$ \\
\hline $\begin{array}{l}1955 \\
\text { Jan. } \\
\text { Feb. } \\
\text { Mar. } \\
\text { Apr. } \\
\text { May } \\
\text { June } \\
\text { July } \\
\text { Ang. } \\
\text { Sept. } \\
\text { Oct. } \\
\text { Nov. } \\
\text { Dec. }\end{array}$ & $\begin{array}{l}16,813 \\
17,183 \\
16,830 \\
17,57 \mathrm{~S} \\
16,908 \\
16,31+ \\
15,514 \\
16,366 \\
17,785 \\
18,146 \\
18,601 \\
17,346\end{array}$ & $\begin{array}{c}\dot{\dagger} \\
\vdots \\
\vdots \\
\vdots \\
\vdots \\
\vdots \\
\vdots \\
\dagger \\
21.8 \div \div \\
110.1 \\
176.3 \\
84.6\end{array}$ & $\begin{array}{l}.53 \\
.54 \\
.53 \\
.55 \\
.53 \\
.51 \\
.48 \\
.51 \\
.55 \\
.56 \\
.58 \\
.54\end{array}$ & 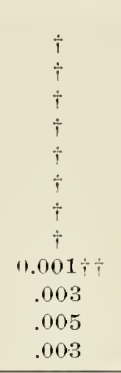 & $\begin{array}{l}31,903 \\
31,932 \\
31,960 \\
31,989 \\
32,017 \\
32,046 \\
32,074 \\
32,103 \\
32,131 \\
32,160 \\
32,185 \\
32,217\end{array}$ \\
\hline $\begin{array}{l}1956 \\
\text { Jan. } \\
\text { Feb. } \\
\text { Mar. } \\
\text { Apr. } \\
\text { May } \\
\text { June } \\
\text { July } \\
\text { Aug. } \\
\text { Sept. } \\
\text { Oct. } \\
\text { Nov. } \\
\text { Dec. }\end{array}$ & $\begin{array}{l}17,673 \\
18,593 \\
18,516 \\
18,172 \\
17,621 \\
17,617 \\
17,492 \\
18,077 \\
19,212 \\
19,866 \\
19,161 \\
18,490\end{array}$ & $\begin{array}{r}75.5 \\
199.5 \\
187.5 \\
254.0 \\
360.9 \\
305.0 \\
304.9 \\
348.4 \\
458.1 \\
492.8 \\
357.5 \\
286.0\end{array}$ & $\begin{array}{l}.55 \\
.58 \\
.57 \\
.56 \\
.54 \\
.54 \\
.54 \\
.56 \\
.59 \\
.61 \\
.59 \\
.57 \\
\end{array}$ & $\begin{array}{l}.002 \\
.006 \\
.006 \\
.008 \\
.011 \\
.009 \\
.009 \\
.011 \\
.014 \\
.015 \\
.011 \\
.009\end{array}$ & $\begin{array}{l}32,245 \\
32,274 \\
32,302 \\
32,331 \\
32,359 \\
32,388 \\
32,416 \\
32,445 \\
32,473 \\
32,502 \\
32,530 \\
32,559\end{array}$ \\
\hline $\begin{array}{l}1957 \\
\text { Jan. } \\
\text { Feb. } \\
\text { Mar. } \\
\text { Apr. } \\
\text { May } \\
\text { June }\end{array}$ & $\begin{array}{l}19,488 \\
19,513 \\
19,049 \\
19,513 \\
18,413 \\
17,080\end{array}$ & $\begin{array}{l}322.6 \\
321.3 \\
278.8 \\
317.6 \\
310.2 \\
287.2\end{array}$ & $\begin{array}{l}.60 \\
.60 \\
.58 \\
.60 \\
.56 \\
.52\end{array}$ & $\begin{array}{l}.010 \\
.010 \\
.009 \\
.010 \\
.009 \\
.009\end{array}$ & $\begin{array}{l}32,587 \\
32,616 \\
32,644 \\
32,673 \\
32,701 \\
32,730\end{array}$ \\
\hline
\end{tabular}

* Compnted from rounded data.

* Estimates centered on 15 th of month.

$\therefore$ No rending machines on location.

fPopulation July 1, 1955 estimated at 32,060: See Sizer, Leonard M., Populution Chune in West Tirginia, 1900-1955, Bul. 401, W. Va., Agr. Exp. Sta., Morgantown, W. Via., May 1957. tonly two machines on location for part of month.

apple processing plants and at some schools had a relatively high volume of sales during this month. During the period from October 1955, to June 1957 , sales of milk through vending machines were 1.5 percent of total milk sales; from January to June 195\%, they were 1.6 percent of total milk sales. 
GALLONS

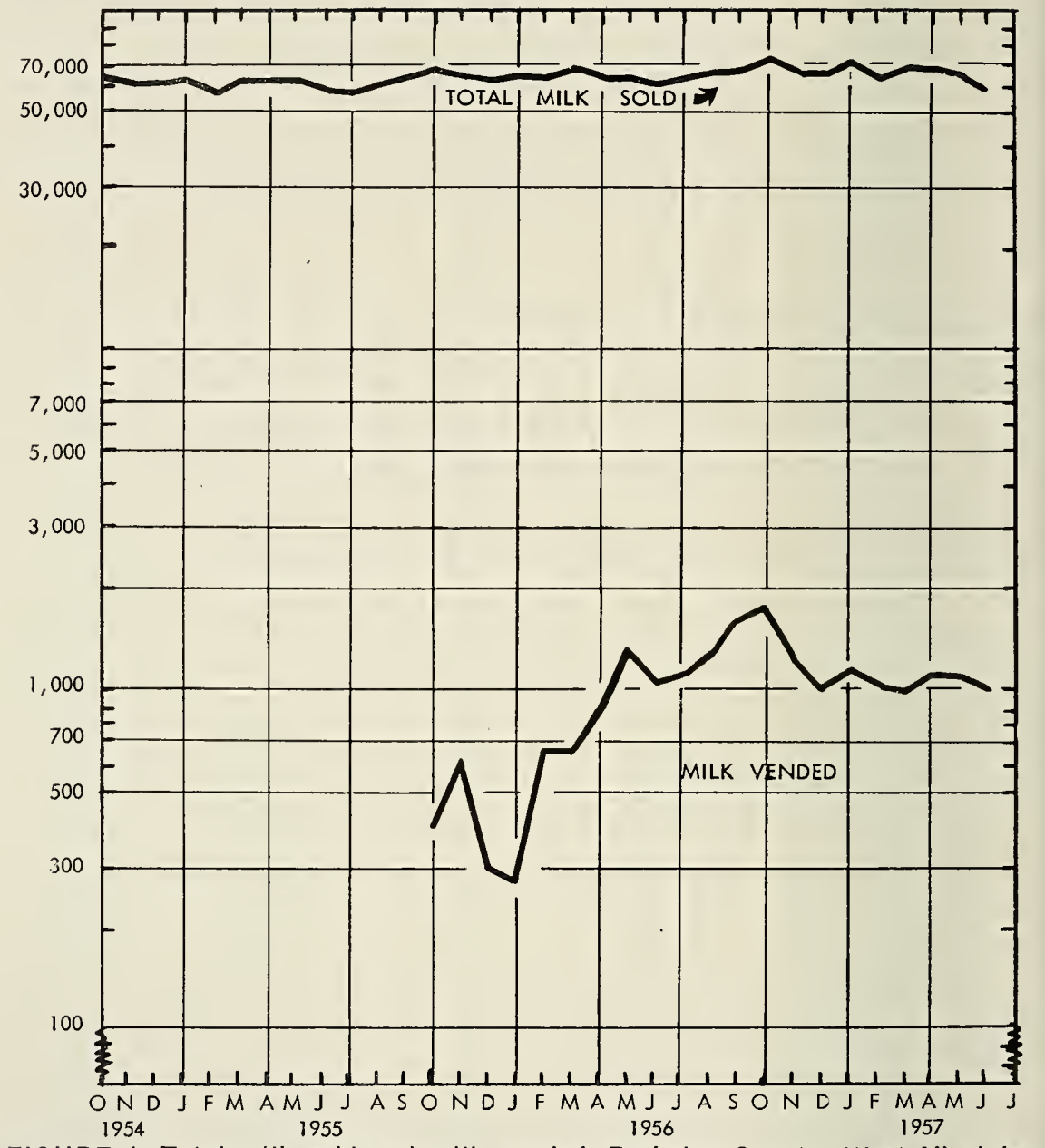

FIGURE 1. Total milk sold and milk vended, Berkeley County, West Virginia October 1957 to June 1957, by months.

\section{PER CAPITA SALES}

During the period October 1954, to September 1955, before vending had been introduced into the market area, per capita sales of milk were 0.52 pounds per day. From October 1955, to June 1957, after the introduction of vending, per capita sales of milk in Berkeley County were 0.57 pounds per day or slightly more than one-half pint per day. ${ }^{1}$ (See Table 2.)

${ }^{1}$ This difference of 0.04 pounds per day was statistically significant at the 0.01 level of probability. However, not all of the difference can be attributed to vending because of changes in the market referred to earlier. 
Daily per capita sales rates, projected to an annual basis, indicated a rate for January-June 1957, of 210 pounds, of which 3.4 pounds may be ascribed to vending. Comparable annual rates computed for the first half of 1956 and the first half of 1955 were 204 pounds (2.6 pounds vending) and 193 pounds (no vending), respectively. Per capita sales which discount the effect of an increased population, were about 9 percent higher in the first half of 1957 than in the corresponding period of 1955. Exclusive of vending this increase in 1957 was only 7 percent.

The per capita rate of milk and cream consumption in the Berkeley County area is apparently well below the national average. Estimates by the United States Department of Agriculture show a 1956 national average rate of 354 poundis per person for fresh whole milk and cream. The estimated rate for the Berkeley County, West Virginia area for the calendar year 1956 , was approximately $252^{2}$ pounds per person or more than one-fourth lower than the United States average.

\section{SALES IN VARIOUS LOCATIONS}

Sales of milk and orange drink through vending machines were made in industrial plants, offices, schools, and in outdoor locations.

\section{Industrial Plants and Offices}

The first two vending machines were placed in industrial plants on September 12, 1955. Seven others were put on location during October, and the number gradually increased until June 1956, when 18 machines were in use in plants and offices. This number was maintained until the end of the study, except that 19 machines were used during April and June 1957.

Throughout the study, sales in these locations were made at a price of ten cents per one-half pint for chocolate milk or drink, orange drink, buttermilk, and homogenized milk. At one location pints of the same products were vended at 15 cents each. At several locations, the milk products competed with bottled or cup-vended soft drinks at five cents per unit. By foregoing any payment for location rental, plants and offices sometimes subsidized the soft-drink items. Lower prices for milk were not feasible under the circumstances, and higher prices were deemed impractical because of milk's competitive situation with soft drinks.

The volumes of sales per machine, by product, together with the number of machines in use are shown in Table 3. Units sold per machine were highest during October 1956, when they averaged 1,144

${ }^{2}$ Estimate based on sales of milk in the area, divided by an estimate of the combined non-farm population and that portion of the farm population living on farms without cows. 


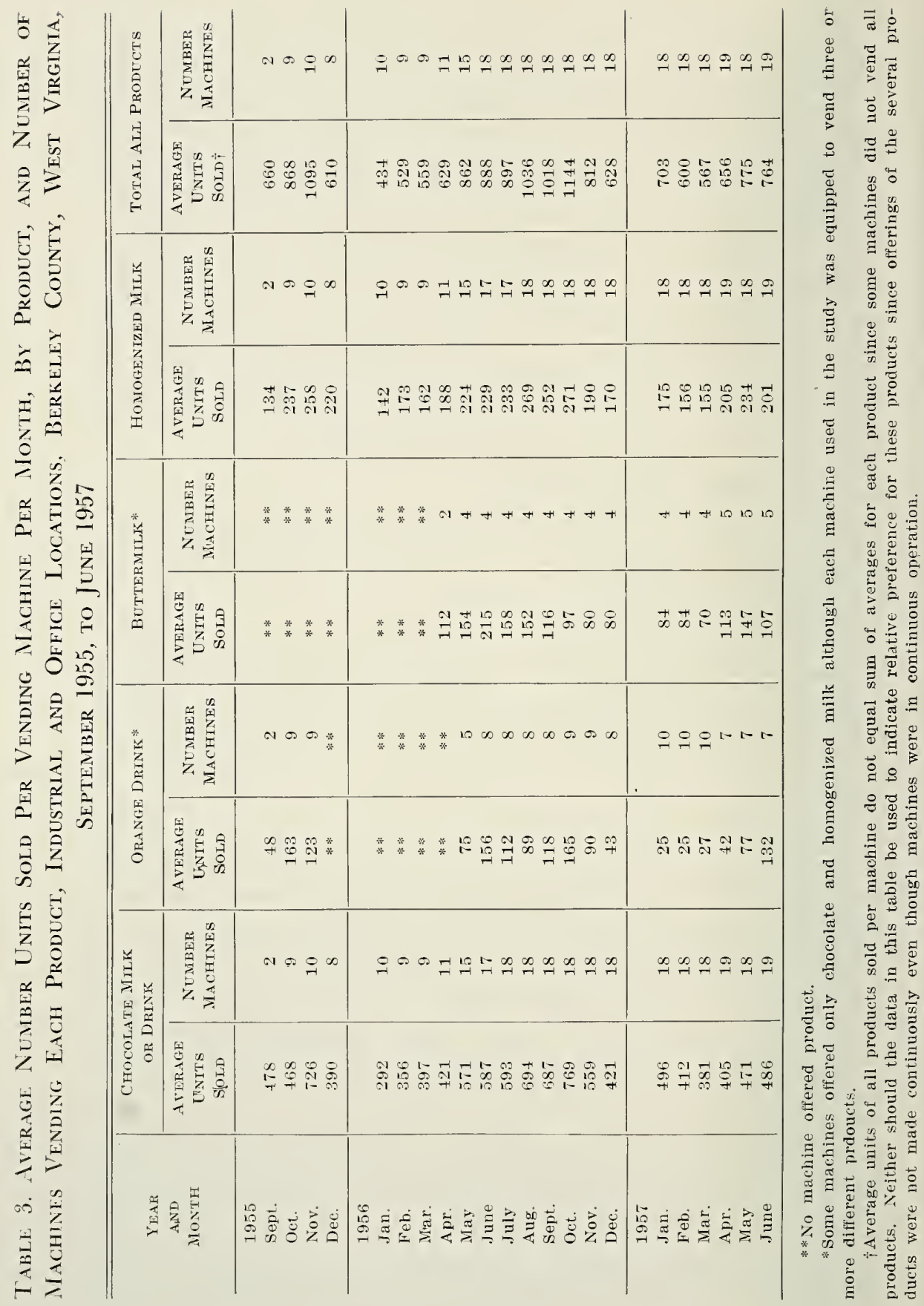


for the 18 machines in use. During the test period, sales per machine were lowest in January 1956, when 10 machines averaged only 434 units. This was prior to the placement of several machines in locations which later resulted in increased average sales per machine. Generally, sales per machine were highest from August to November because three large-volume machines in seasonally-operated apple processing plants increased the average substantially during this period.

Although the average sales of all products per machine were not high, considerable variation in the sales per machine occurred among the different locations where vending machines were operating. Variations in sales volume during the period each machine operated also were observed. These variations are portrayed in Figures 2 to 8 . There was a tendency for sales at many locations to decline substantially after the initial installation of the machines. For several machines, a downrard trend in sales occurred during the entire period the machines were in use.

Exceptions to this downward treind in the following locations were observed: (1) in plants with much variation in seasonal employment (such as G, P, and Q); (2) where volume was so low that operations were not profitaible (such as $\mathrm{I}, \mathrm{N}$, and $\mathrm{R}$ ); and (3) instailations made in the winter in plants where business activity increased as the season became warmer (such as J).

Sales per machine at each location where the machines were in continuous use, for consecutive full months of operation, are shown in Table 4. This tabulation ignores the season of the year in which the installation was made and shows the change in sales as machines were operated at a single location over an extended period of time. Sales per machine cluring the first full month of operation averaged 1,400 units, but by the corresponding month a year later (thirteenth month) per-machine sales had dropped to 665 . The machines in operation for 15 months or longer included those at locations A, B, H, I, K, M, O, P, and $R$. These machines had a lower average volume per machine than the entire group and account, in part, for the lower average sales per machine for the period from the fifteenth to the twenty-first month of operation.

\section{Schools}

Two semi-automatic vending machines were installed in tro clementary schools on February 1, 1956. A third semi-automatic machine was installed in another elementary school on February 15, 1956, and a fourth machine of the same type in a fourth elementary school 


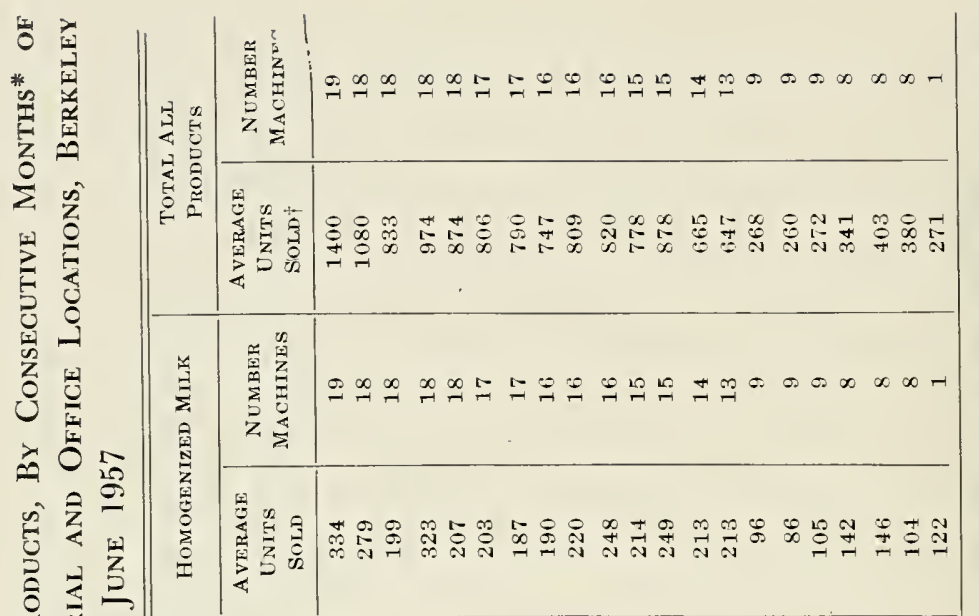

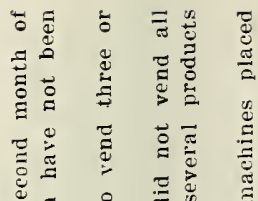

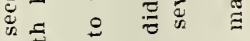

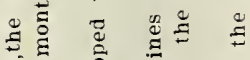

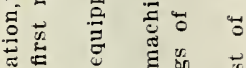

ฐ

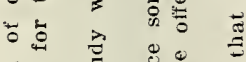

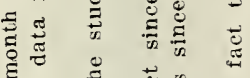

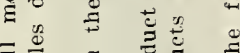

छ

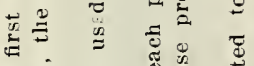

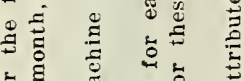

ह ङ क्ष

ษ

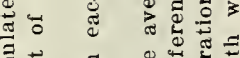

苛范

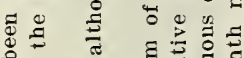

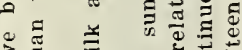

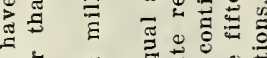

离

क o

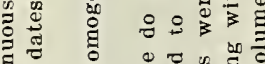

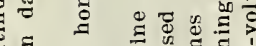

¿ व

$\Xi \stackrel{0}{=} \quad$ a

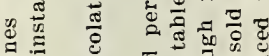

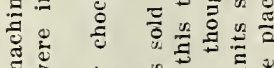

घ $\geq \geq$

เ

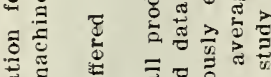
สํํำ

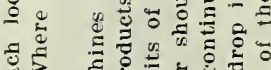

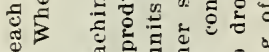

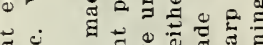

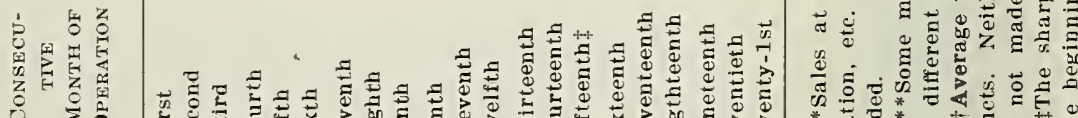

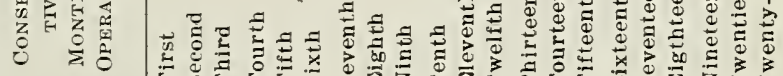

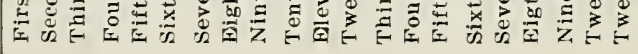



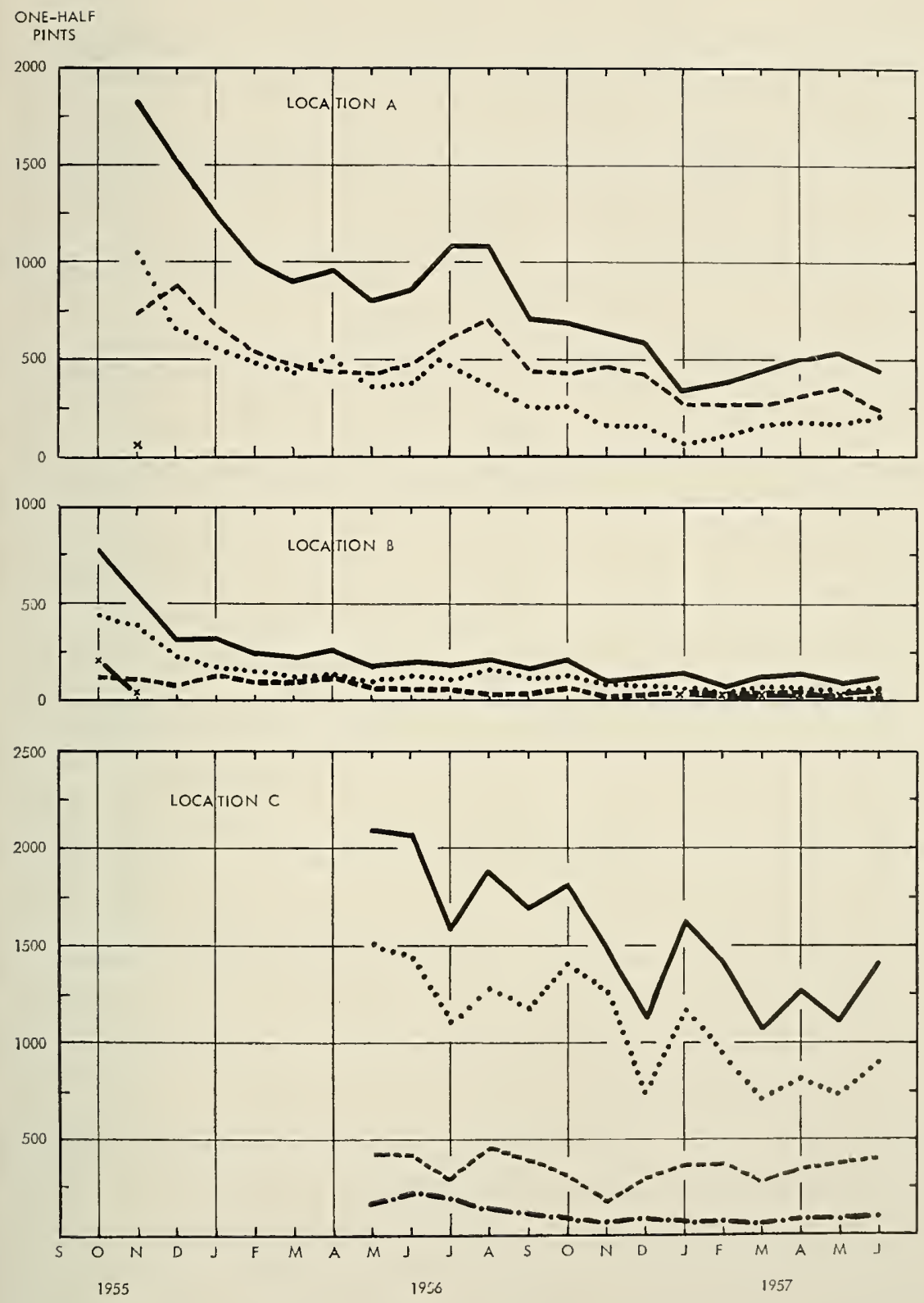

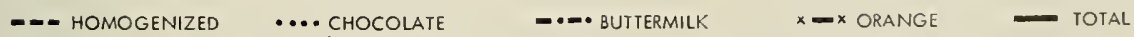

FIGURE 2. Milk and orange drink sold through vending machines at locations A, B, and C, Berkeley County, West Virginia, October 1955 to June 1957, by months. 

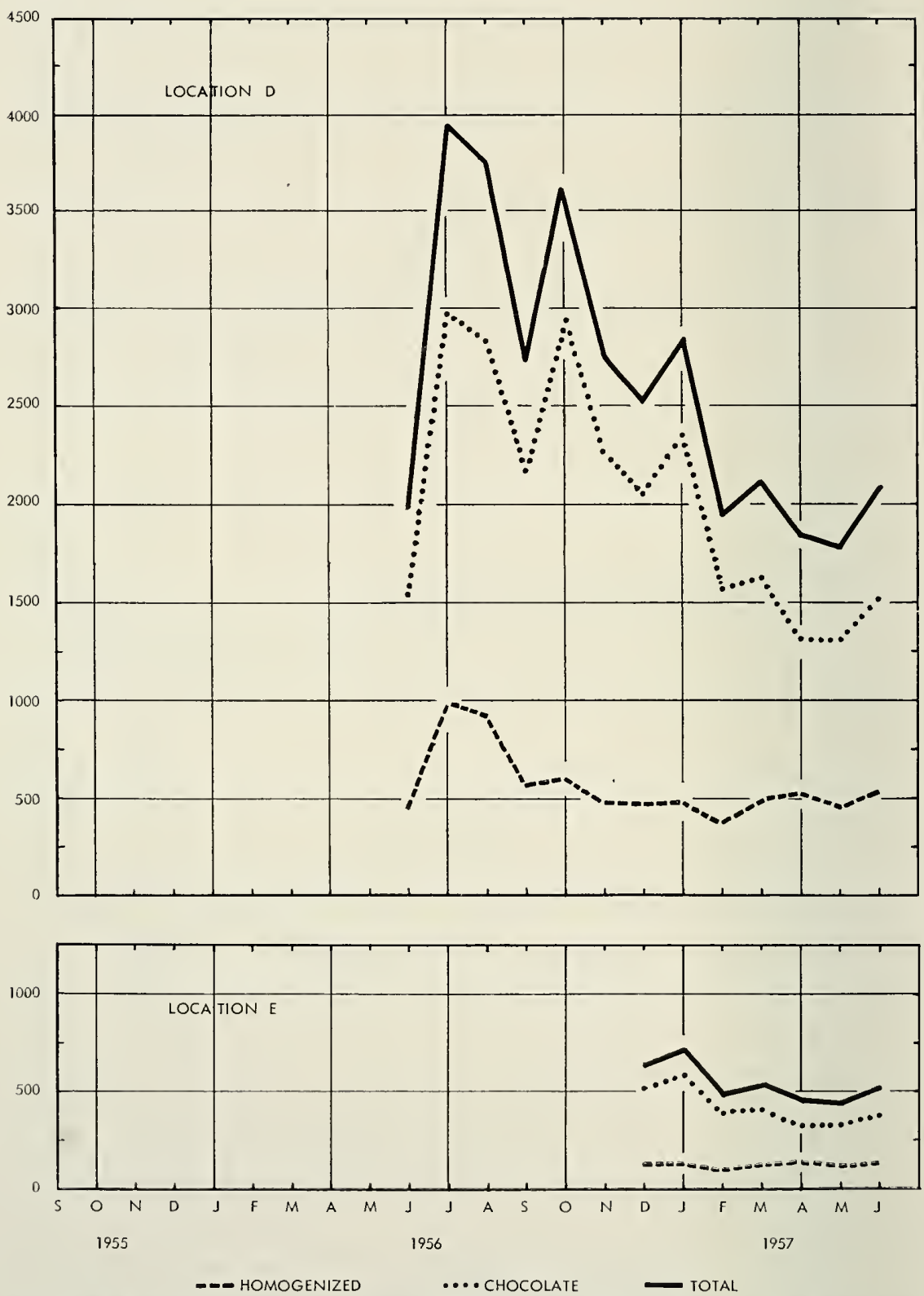

FIGURE 3. Milk sold through vending machines at locations $D$ and $E$, Berkeley County, West Virginia, June 1956 to June 1957, by months. 

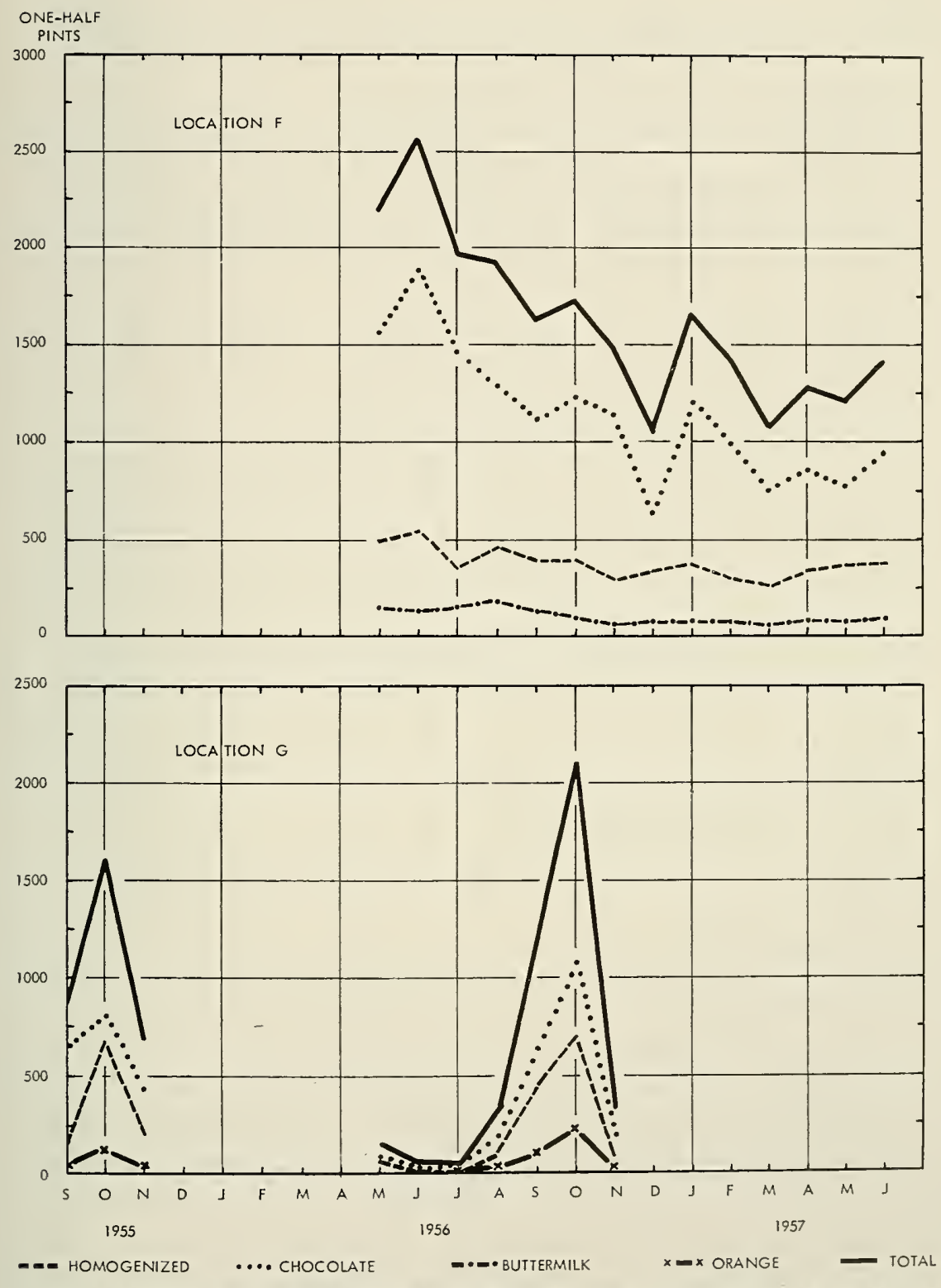

FIGURE 4. Milk and orange drink sold through vending machines at locations F and G, Berkeley County, West Virginia, September 1955 to June 1957, by months. 

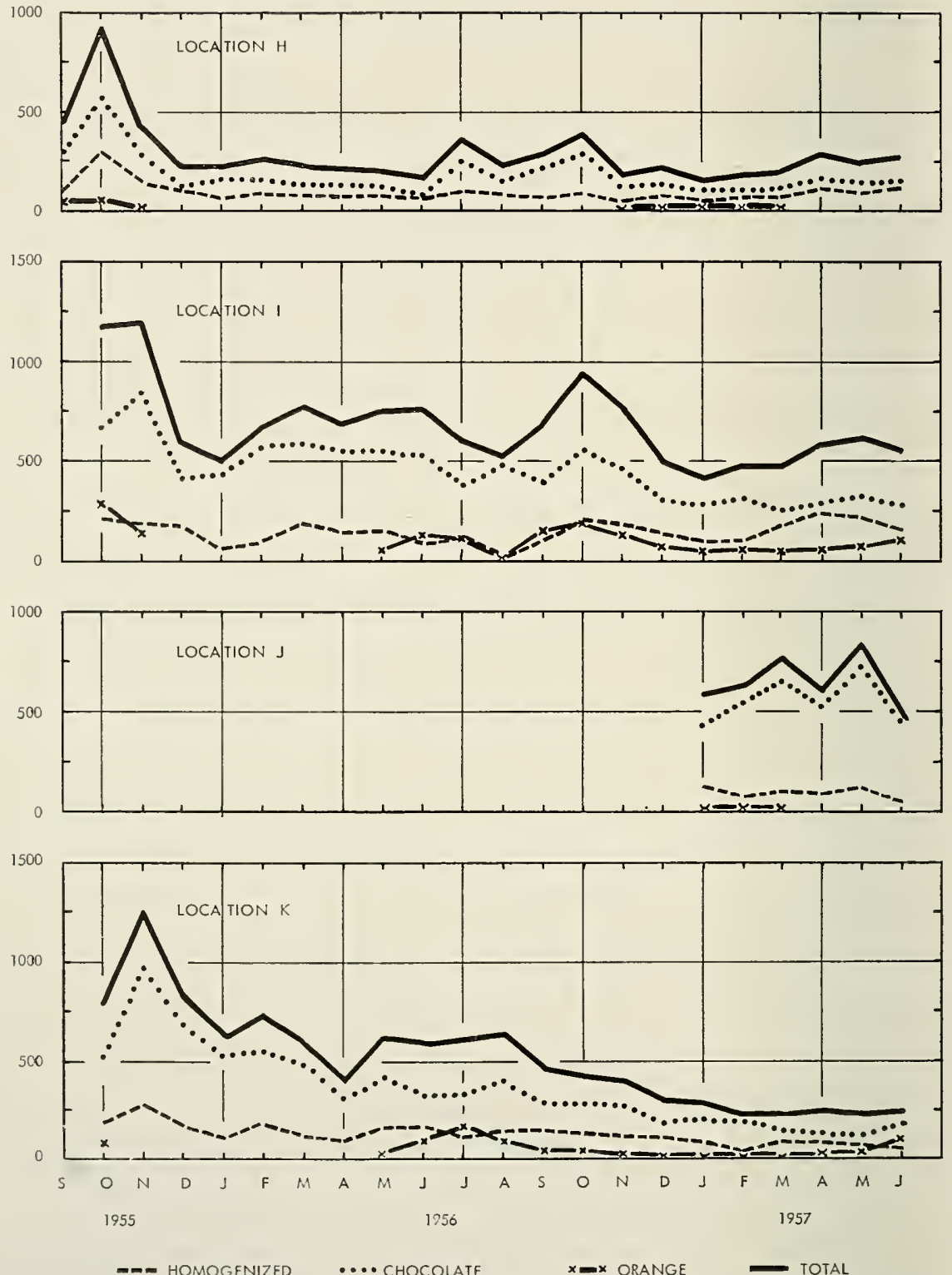

FIGURE 5. Milk and orange drink sold through vending machines at locations $\mathrm{H}, \mathrm{I}, \mathrm{j}$, and K, Berkeley County, West Virginia, September 1955 to June 1957, by months. 

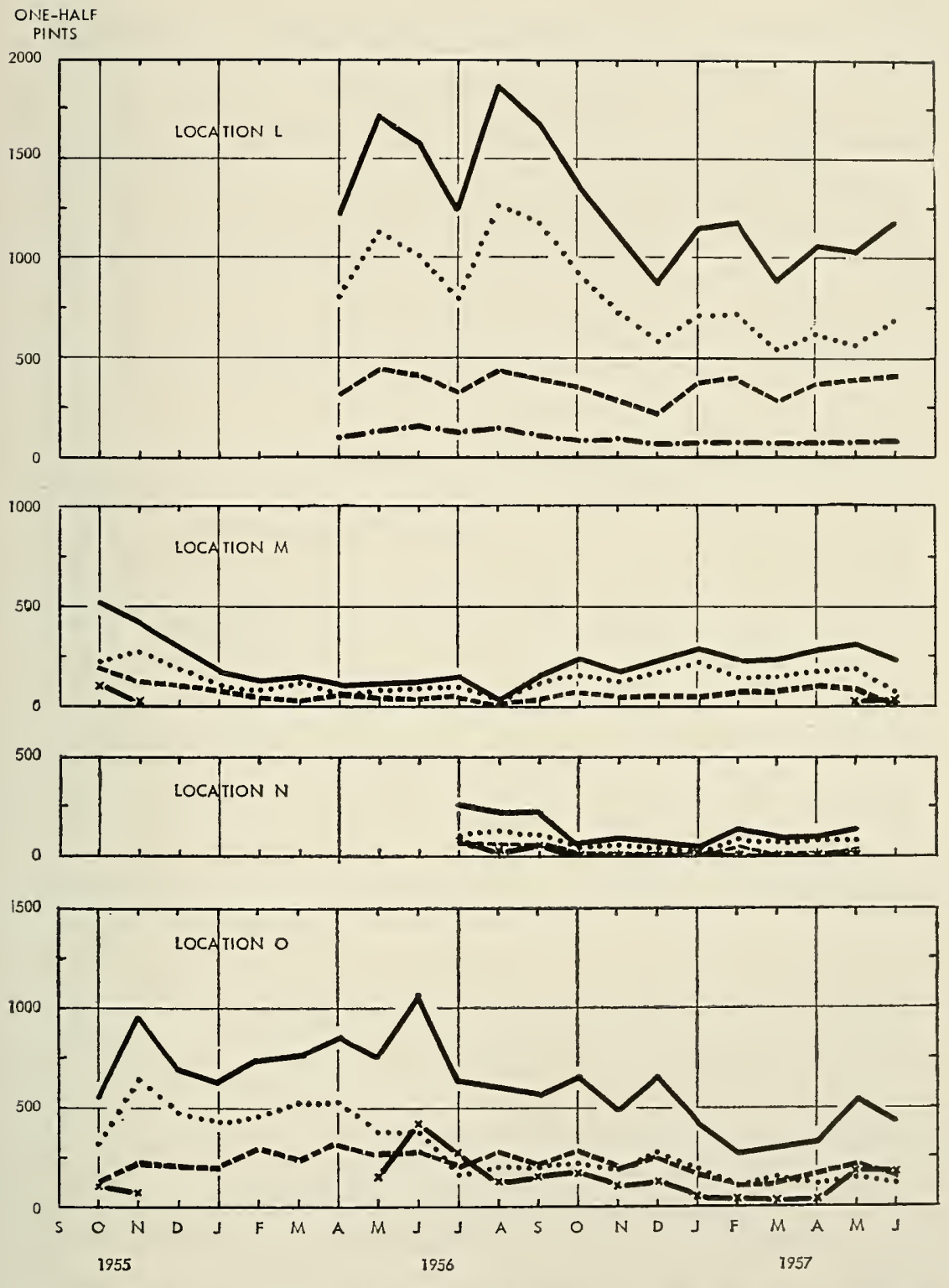

-2 HOMOGENIZED $\quad$-... CHOCOLATE

FIGURE 6. Milk and orange drink sold through vending machines at locations $L, M, N$, and $O$, Berkeley County, West Virginia, October 1955 to June 1957, by months. 

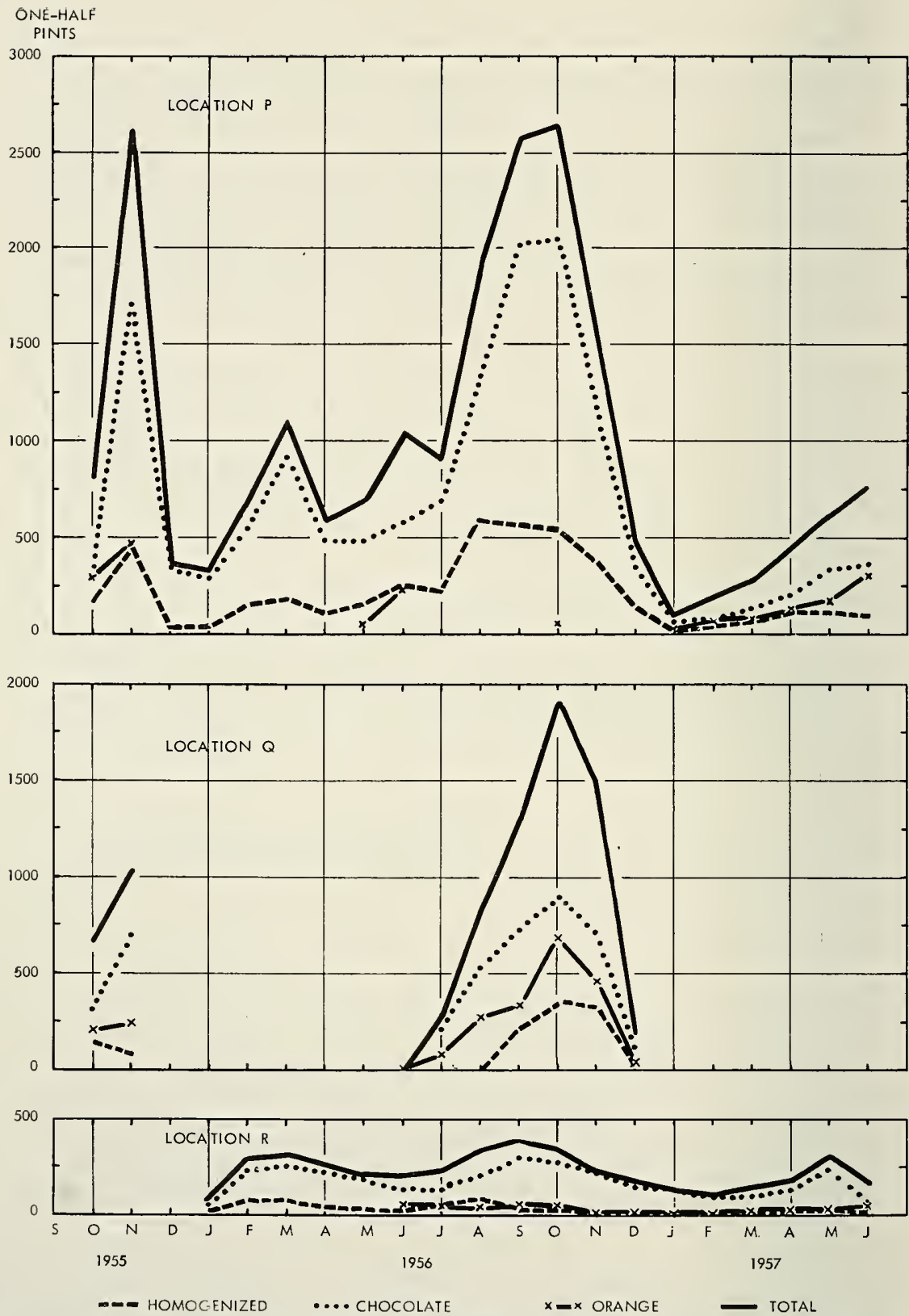

FIGURE 7. Milk and orange drink sold through vending machines at locations $P, Q$, and R, Berkeley County, West Virginia, October 1955 to June 1957, by months. 

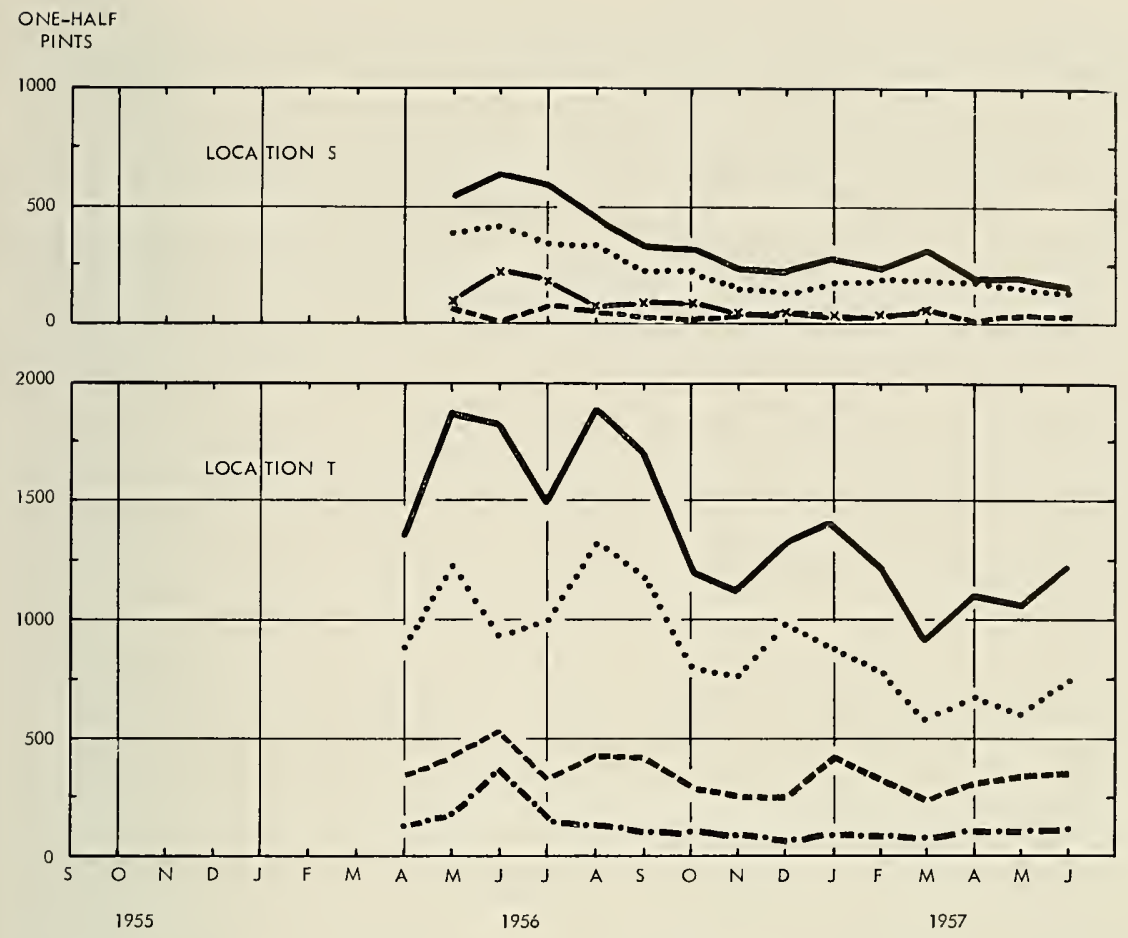

- - HOMOGENIZED $\quad$-... CHOCOLATE -... BUTIERMILK $\quad$ - $\times$ ORANGE DOTAL

FIGURE 8. Milk and orange drink sold through vending machines at locations $\mathrm{S}$ and $\mathrm{T}$, Berkeley County, West Virginia. October 1955 to June 1957, by months.

on May 1, 1956. Two automatic machines were placed in another combined elementary and junior high school at the beginning of the school year in September, 1956.

Homogenized milk was vended at a price of three cents per onehalf pint in all schools studied, except school S-III. At this school, the price was two cents per one-half pint. Students at school S-V were offered chocolate milk at five cents and homogenized milk at three cents per one-half pint, both in vending machines. The difference between these prices and the milk distributors' wholesale prices to schools was made up by subsidies provided under the Special Milk Program.

In Table 5, sales of milk at these locations are compared with the sales of milk through the School Lunch and Special Milk Programs at the same schools. Prior to beginning milk vending in these schools, the milk distributors in the city had made milk available to the students under the Special Milk Program. A routeman usually had arrived at a school just before the recess period and had stayed during the'recess to sell milk 
Table 5. Milk Sales Through Vending Machines, the School Lunch Program, and the Special Milk Program, and Total Daily Consumption Per Student in Selected Schools, Berkeley County, West Virginia, November 1954, To MaY 1957, By Months

\begin{tabular}{|c|c|c|c|c|c|c|}
\hline \multirow{2}{*}{$\begin{array}{c}\text { YEAR } \\
\text { A.ND } \\
\text { MONTH }\end{array}$} & \multirow[b]{2}{*}{ TOTAL } & \multirow[b]{2}{*}{$\begin{array}{l}\text { VENDING } \\
\text { MACHINES * }\end{array}$} & \multicolumn{2}{|c|}{ OTHER } & \multirow[b]{2}{*}{ ScHOOLS } & \multirow{2}{*}{$\begin{array}{l}\text { TOTAL DAILY } \\
\text { CONSUMPTION } \\
\text { PER STUDENT } \\
\text { AT SCHOOL** }\end{array}$} \\
\hline & & & $\begin{array}{c}\text { LUNCH } \\
\text { Progran }\end{array}$ & $\begin{array}{c}\text { SPECIAL } \\
\text { MiLK } \\
\text { Program }\end{array}$ & & \\
\hline $\begin{array}{l}1954 \\
\text { Oct. } \\
\text { Nov. } \\
\text { Dec }\end{array}$ & $\begin{array}{r}1 / 2 \quad P t . \\
7,923 \\
7,173\end{array}$ & $\begin{array}{l}1 / 2 P t . \\
\text { None } \\
\text { None }\end{array}$ & $\begin{array}{r}1 / 2 \quad P t . \\
6,786 \\
5,760\end{array}$ & $\begin{array}{r}1 / 2 \quad P t \\
1,137 \\
1,413\end{array}$ & Number & $\begin{array}{c}1 / 2 \quad P t . \\
\\
.75 \\
.65\end{array}$ \\
\hline $\begin{array}{l}1955 \\
\text { Jan. } \\
\text { Feb. } \\
\text { Mar. }\end{array}$ & $\begin{array}{l}18,411 \\
14,032 \\
16,061\end{array}$ & $\begin{array}{l}\text { None } \\
\text { None } \\
\text { None }\end{array}$ & $\begin{array}{l}7,917 \\
7,163 \\
8,671\end{array}$ & $\begin{array}{r}10,494 \\
6,869 \\
7,390\end{array}$ & $\begin{array}{l}5 \\
5 \\
5\end{array}$ & $\begin{array}{l}.61 \\
.48 \\
.52\end{array}$ \\
\hline $\begin{array}{l}\text { Apr. } \\
\text { May }\end{array}$ & $\begin{array}{r}11,086 \\
8,621\end{array}$ & $\begin{array}{l}\text { None } \\
\text { None }\end{array}$ & $\begin{array}{l}6,471 \\
5,464\end{array}$ & $\begin{array}{l}4,615 \\
3,157\end{array}$ & $\begin{array}{l}5 \\
5\end{array}$ & $\begin{array}{l}.35 \\
.27\end{array}$ \\
\hline $\begin{array}{l}\text { Sept. } \\
\text { Oct. } \\
\text { Nov. } \\
\text { Dec. }\end{array}$ & $\begin{array}{r}9,468 \\
13,918 \\
12,483 \\
8,978 \\
\end{array}$ & $\begin{array}{l}\text { None } \\
\text { None } \\
\text { None } \\
\text { None }\end{array}$ & $\begin{array}{l}4,854 \\
6,709 \\
6,779 \\
5,129 \\
\end{array}$ & $\begin{array}{l}4,614 \\
7,209 \\
5.704 \\
3,849 \\
\end{array}$ & $\begin{array}{l}5 \\
5 \\
5 \\
5\end{array}$ & $\begin{array}{l}.29 \\
.45 \\
.41 \\
28 \\
\end{array}$ \\
\hline $\begin{array}{l}1956 \\
\text { Jan. } \\
\text { Feb. } \\
\text { Mar. }\end{array}$ & $\begin{array}{l}12,688 \\
15,079 \\
13,741\end{array}$ & $\begin{array}{l}\text { None } \\
5,623 \\
5,139\end{array}$ & $\begin{array}{l}6,587 \\
7,212 \\
6,778\end{array}$ & $\begin{array}{l}6,101 \\
2,262 \\
1,824\end{array}$ & $\begin{array}{l}5 \\
5 \\
5\end{array}$ & $\begin{array}{l}.41 \\
.45 \\
.45\end{array}$ \\
\hline $\begin{array}{l}\text { Apr. } \\
\text { May }\end{array}$ & $\begin{array}{l}12,299 \\
11,030\end{array}$ & $\begin{array}{l}4,536 \\
5,961\end{array}$ & $\begin{array}{l}6,334 \\
4,774\end{array}$ & $\begin{array}{r}1,429 \\
295\end{array}$ & $\begin{array}{l}5 \\
5\end{array}$ & $\begin{array}{l}.38 \\
.35\end{array}$ \\
\hline $\begin{array}{l}\text { Sept } \\
\text { Oct. } \\
\text { Nov. } \\
\text { Dec. }\end{array}$ & $\begin{array}{l}13,322 \\
19,658 \\
14,602 \\
10,649 \\
\end{array}$ & $\begin{array}{l}5,991 \\
7,013 \\
4,367 \\
2,843 \\
\end{array}$ & $\begin{array}{r}7,331 \\
12,645 \\
10,235 \\
7,806\end{array}$ & $\begin{array}{l}\dagger \\
\dagger \\
\dagger \\
\dagger\end{array}$ & $\begin{array}{l}5 \\
5 \\
5 \\
5\end{array}$ & $\begin{array}{l}.39 \\
.55 \\
.48 \\
.31 \\
\end{array}$ \\
\hline $\begin{array}{l}1957 \\
\text { Jan. } \\
\text { Feb. } \\
\text { Mar. }\end{array}$ & $\begin{array}{l}16,019 \\
15,581 \\
15,266\end{array}$ & $\begin{array}{l}4,069 \\
4,377 \\
4,109\end{array}$ & $\begin{array}{l}11,950 \\
11,204 \\
11.157\end{array}$ & $\begin{array}{l}\dagger \\
\dagger \\
\dagger\end{array}$ & $\begin{array}{l}5 \\
5 \\
5\end{array}$ & $\begin{array}{l}.48 \\
.44 \\
.45\end{array}$ \\
\hline $\begin{array}{l}\text { Apr. } \\
\text { May }\end{array}$ & $\begin{array}{l}14,473 \\
11,826\end{array}$ & $\begin{array}{l}3,613 \\
2,468\end{array}$ & $\begin{array}{c}10,860 \\
9,358\end{array}$ & $\grave{t}$ & $\begin{array}{l}5 \\
5\end{array}$ & $\begin{array}{r}.41 \\
34\end{array}$ \\
\hline
\end{tabular}

* Milk vending started in two schools on February 1, 1956, in one sehool on February 15, 1956, in one on May 1, 1956, and in one in September, 1956. One school discontinued vending and its special milk program in September 1956 after starting a school lunch program.

** Total consumption in schools of one-half pint unlts eack month divided by the monthly school attendance for the corresponding schools and months. vended.

†After September 1956, all Special-Milk-Program sales through these schools were

to the students. Usually, he had opened the container for the students, collected payment, and furnished straws. This practice was discontinued at the schools after the installation of milk vending machines, and the two milk distributors involved indicated that the change was greatly preferred by them. Increased responsibilities were thrown on teachers 
and principals, however, because they were required to supervise the Special Milk Program more closely when it was operated through vending machines.

Figures 9 and 10 show the sales at each school location during the period covered by the study. In general, sales declined after the first few months of operation. This may be attributed, in part, to the novelty effect of milk vending and its gradual decline. However, a similar decline in the sale of milk under the Special Milk Program occurred in several schools before the introduction of vending machines. One school principal attributed the decline in sales at his school to the reduced purchasing power of the parents who often had opportunity for employment in the seasonal apple industry during the fall and winter but whose monetary accumulations made during this period gradually diminished as the school year proceeded. Sales of milk through the School Lunch Program also declined at this school but less than the sale of milk through vending machines.

Per student consumption of milk in the school locations studied is shown in Table 6. Per student consumption was higher in school S-V in October 1956, following the introduction of rending nachines. Sales were relatively higher in this school and school S-III than in the other schools studied. Both had School Lunch Programs in addition to the Special Milk Program. School S-IV showed increased per student sales when its Special Lunch Program replaced the Special Milk Program (vended) in September 1956.

Sales of milk were low in School S-II. In this school, milk sales competed with ice cream bars and ice cream cups. However, similar competition existed at school S-III, where both vended consumption and total consumption were much higher. School S-III also had a School Lunch Program, while school S-II had no Iunch program.

The Special Milk Program sales before and after the introduction of vending are shown in Table 7 . Per student sales of milk in the Special Milk Program at school S-V were higher than in the other schools, both before and after the introduction of vending. It this school, both homcgenized and chocolate milk were offered to the students in the vending machines. The ratio of homogenized to chocolate milk sales is shown on Figure 10. The principal at this school also indicated that students who had purchased homogenized milk muder the Special Milk Program before the introduction of rended chocolate milk had been furnished chocolate syrup which could be mixed with milk.

Comparison of total and Special-Milk-Program milk sales in schools before and after the introduction of milk vending machines is shown in Tables 7 and 8. Special-Milk-Program milk sales were 51 percent higher 

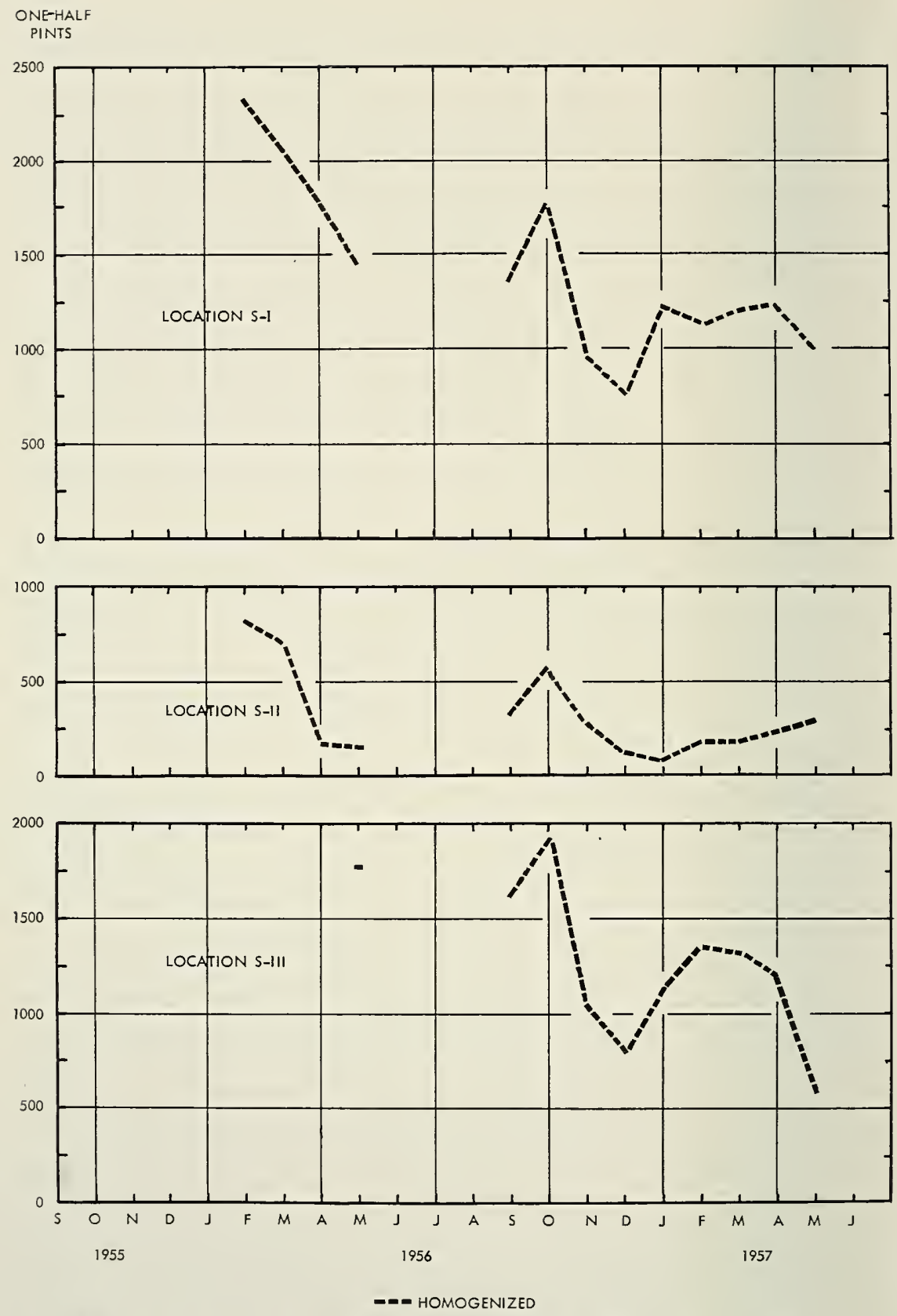

FIGURE 9. Milk sold through vending machines at school locations S-I, S-II, and S-III, Berkeley County, West Virginia, February 1956 to May 1957, by months. 

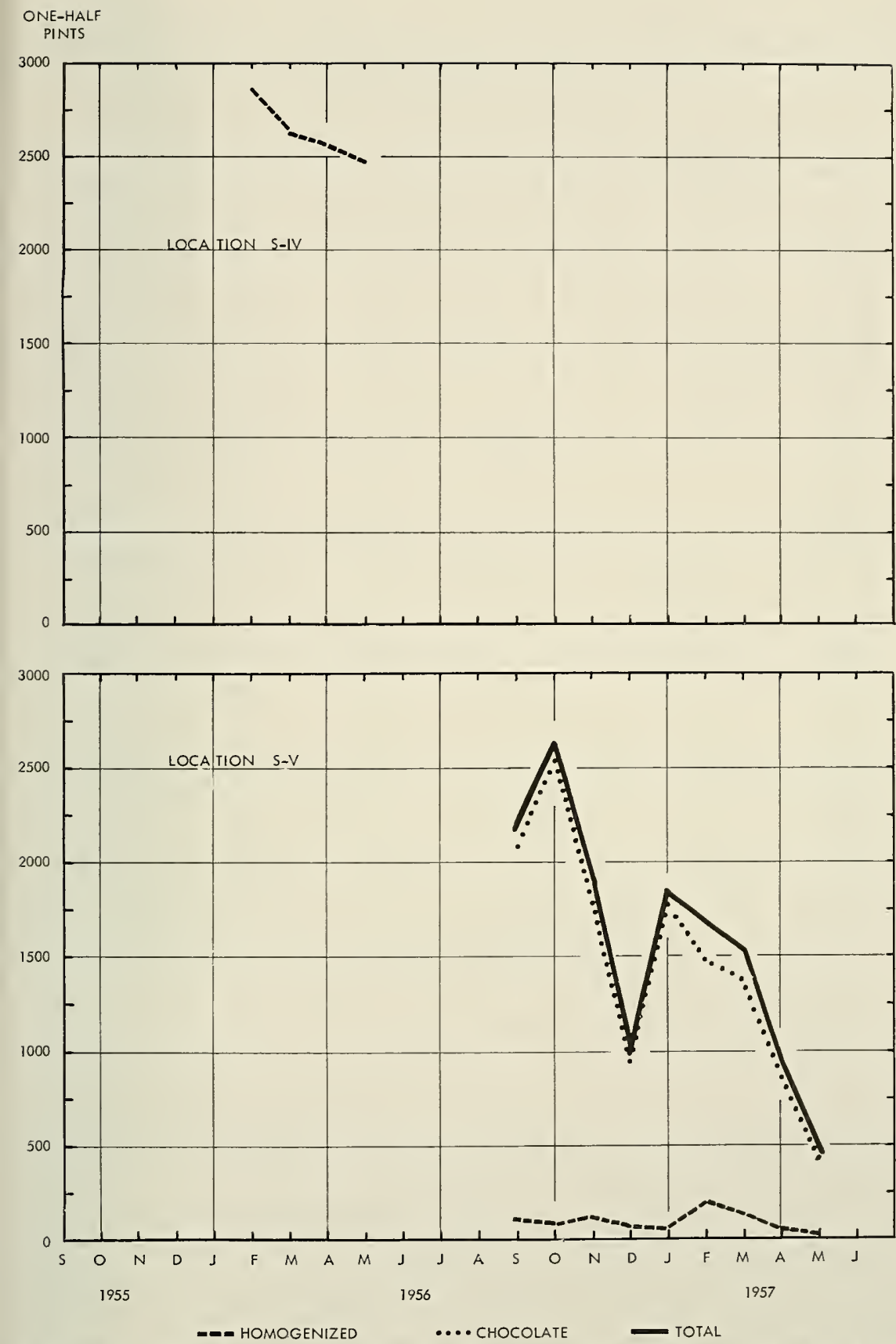

FIGURE 10. Milk sold through vending machines at school locations S-IV and S-V, Berkeley County, West Virginia, February 1956 to May 1957, by months. 
Table 6. Dally Per Student Consumption of Milk at Berkeley County West Virginia Schools Using Milk Vending Machines, School Years 1954-55 то $1956-57$

\begin{tabular}{|c|c|c|c|c|c|}
\hline \multirow{3}{*}{$\begin{array}{c}\text { MONTH } \\
\text { AND } \\
\text { YEAR }\end{array}$} & \multicolumn{5}{|c|}{ Daily Per StUdent MiLK Consumption* at Schoor, } \\
\hline & \multicolumn{5}{|c|}{ ScHOOL } \\
\hline & S-I & S-II & S-III & S-IV & $S-V$ \\
\hline $\begin{array}{l}\text { Sept. ' } 54 \\
\text { Oet. } \\
\text { Nov. } \\
\text { Dec. }\end{array}$ & $\begin{array}{l}* * \\
* * \\
* * \\
* *\end{array}$ & $\begin{array}{l}* * \\
* * \\
* * \\
* *\end{array}$ & $\begin{array}{c}\text { One-half Pints } \\
* * \\
* * \\
.70 \dagger \dagger-\dagger \\
.61 \\
\end{array}$ & $\begin{array}{l}* * \\
* * \\
* * \\
*\end{array}$ & $\begin{array}{l}* * \\
* * \\
.94 \div \dagger-\dagger \\
.81 \\
\end{array}$ \\
\hline $\begin{array}{l}\text { Jan. '55 } \\
\text { Feb. } \\
\text { Mar. } \\
\text { Apr. } \\
\text { May } \\
\text { Sept. '55 } \\
\text { Oct. } \\
\text { Nov. } \\
\text { Dec }\end{array}$ & $\begin{array}{l}.74 \dagger \\
.49 \\
.42 \\
.25 \\
.18 \\
.19 \\
.44 \\
.35 \\
.20 \\
\end{array}$ & $\begin{array}{l}.29 \dagger \\
.09 \\
.08 \\
04 \\
.06 \\
.03 \\
.09 \\
.04 \\
.03 \\
\end{array}$ & $\begin{array}{l}.78 \\
.73 \\
.88 \\
.65 \\
.56 \\
.48 \\
.65 \\
.66 \\
.46 \\
\end{array}$ & $\begin{array}{l}.54 \dagger \\
.31 \\
.27 \\
.16 \\
.13 \\
.33 \\
.43 \\
.38 \\
.23 \\
\end{array}$ & $\begin{array}{r}1.00 \\
1.34 \\
1.50 \\
1.02 \\
.44 \\
.70 \\
1.12 \\
1.12 \\
.97 \\
\end{array}$ \\
\hline $\begin{array}{l}\text { Jan. '56 } \\
\text { Feb. } \\
\text { Mar. } \\
\text { Apr. } \\
\text { May } \\
\text { Sept. ' } 56 \\
\text { Oct. } \\
\text { Nov. } \\
\text { Dec. }\end{array}$ & $\begin{array}{l}.36 \\
.39 \% \\
.36 \\
.30 \\
.25 \\
.21 \\
.26 \\
.18 \\
.13 \\
\end{array}$ & $\begin{array}{l}.03 \\
.09 \\
.06 \\
.02 \\
.01 \\
.03 \\
.05 \\
.03 \\
.02 \\
\end{array}$ & $\begin{array}{l}.66 \\
.67 \\
.68 \\
.61 \\
.76+ \\
.66 \\
.92 \\
.80 \\
.53 \\
\end{array}$ & $\begin{array}{l}.31 \\
.40 \div \\
.41 \\
.38 \\
.35 \\
.31 \div \div-4+ \\
.57 \\
.53 \\
.39 \\
\end{array}$ & $\begin{array}{c}1.36 \\
1.34 \\
1.39 \\
1.12 \\
.44 \\
1.37 ! \\
1.58 \\
1.43 \\
.84 \\
\end{array}$ \\
\hline $\begin{array}{l}\text { Jan. } 57 \\
\text { Feb. } \\
\text { Mar. } \\
\text { Apr. } \\
\text { May }\end{array}$ & $\begin{array}{l}.20 \\
.17 \\
.20 \\
.19 \\
.16\end{array}$ & $\begin{array}{l}.02 \\
.02 \\
.02 \\
.02 \\
.03\end{array}$ & $\begin{array}{r}.78 \\
.73 \\
.75 \\
.70 \\
56\end{array}$ & $\begin{array}{l}.64 \\
.58 \\
.59 \\
.54 \\
48\end{array}$ & $\begin{array}{r}1.34 \\
1.17 \\
1.15 \\
.85 \\
.71\end{array}$ \\
\hline
\end{tabular}

*Daily per student consumption is total milk sold in each school each month divided by the monthly sum of the number of students present each day during the month.

**No milk served or no record of School Lunch Milk.

$\div$ Special Milk Program started.

†Vending started.

$\uparrow+$ School Lunch Program in use or started this month.

样Vending discontinued.

in the five schools after the introduction of vending than during the corresponding months a year earlier, although sales declined at two of the five schools. The increase occurred even though milk distributors, prior to the introduction of vending, had been providing special service ${ }^{3}$ under the Special Milk Program. Total milk sales at the same schools and for the same months were 26 percent higher during vending than before the introduction of vending machines. During the same period, daily attendance at the schools increased only 7 percent.

"As inclicated on page 25. 
Table 7. Sales of Special-Milk-Program Milk at Schools Before ani After Installation of Vending Machines, Martinsburg, West Virginia, February 1955, to January 1957

Special Milk Sales (Before Vending)

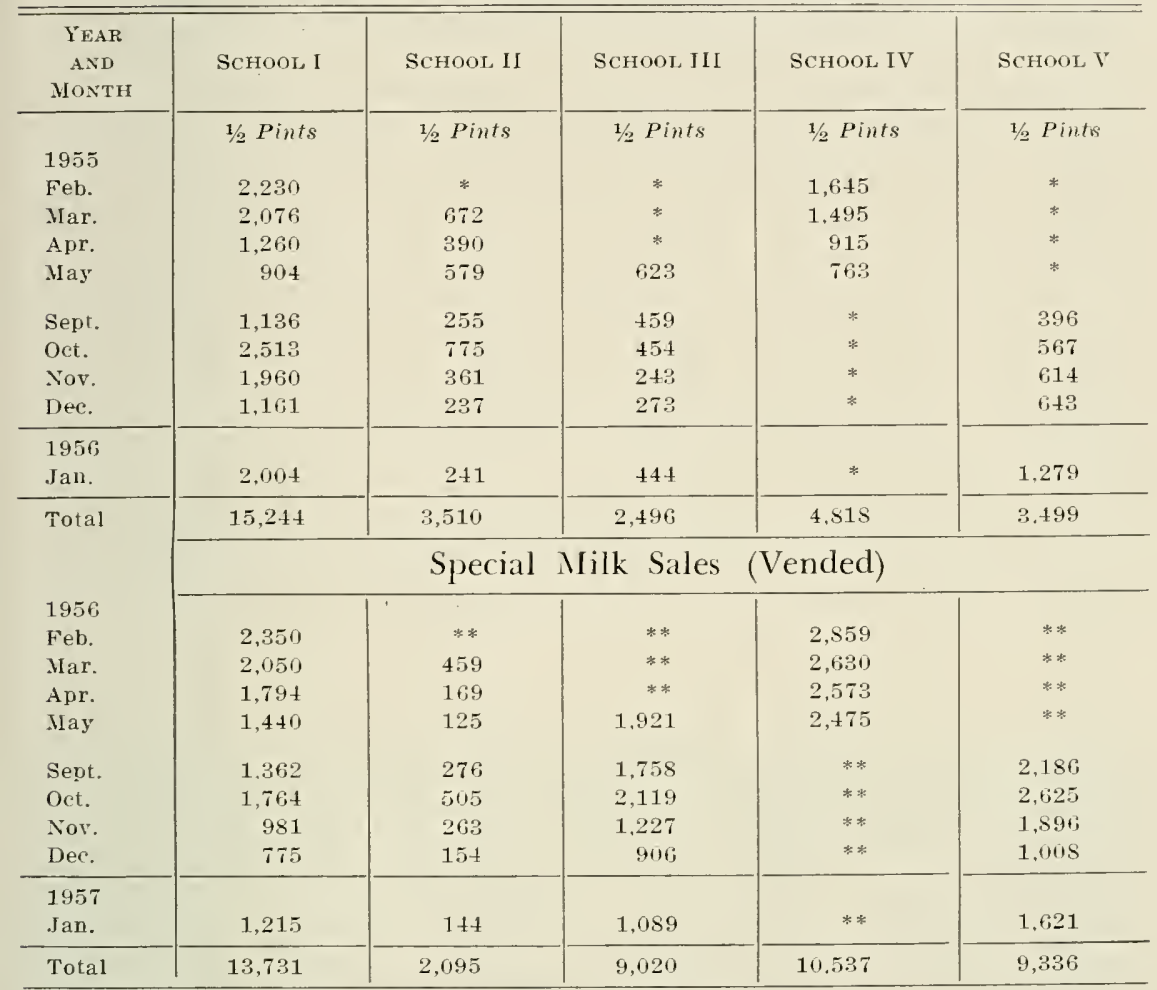

Total five schools, before vending- 29,567 one-half pints.

Total five schools, vended-14,719 one-half pints.

*Data not used because vending not in use for the corresponding month a year later. **Vending not used.

\section{Maximum Use Tests in Schools}

Early in November 1957, a test was made in a grade school to determine the volume of milk which would be vended through an antomatic vending machine during a limited period of time. The milk vending machine had been in use at the school for about two months and the children were familiar with its operation and were able to use it without difficulty. The machine used offered, at a price of four cents, only chocolate milk in one-half pint paper cartons. The coin mechanism accepted only a five-cent coin and gave one cent in change. 
Table 8. Total Sales of Milk at Schools Before and After InstallAtion of Vending Machines, Martinsburg, West Virginia, February 1955, TO JANUARY 1957

Total Milk Sales (Before Vending)

\begin{tabular}{|c|c|c|c|c|c|}
\hline $\begin{array}{c}\text { YEAR } \\
\text { AND } \\
\text { MONTH }\end{array}$ & ScHOOL I & ScHOOL II & ScHOоL III & School IV & ScHOOL V \\
\hline 1955 & $1 / 2$ Pints & 1/2 Pints & $1 / 2$ Pints & $1 / 2$ Pints & $1 / 2$ Pints \\
\hline Feb. & 2,230 & * & * & 1,645 & * \\
\hline Mar. & 2,076 & 672 & * & 1,495 & * \\
\hline Apr. & 1,260 & 390 & * & 915 & * \\
\hline May & 904 & 579 & 5,247 & 763 & * \\
\hline Sept. & 1,136 & 255 & 3,933 & * & 1,776 \\
\hline Oct. & 2,513 & 775 & 5,035 & * & 2,695 \\
\hline Nov. & 1.960 & 361 & 4,980 & * & 2,656 \\
\hline Dec. & 1,161 & 237 & 3,685 & $*$ & 2,360 \\
\hline $\begin{array}{l}1956 \\
\text { Jan. }\end{array}$ & 2,004 & 241 & 5,130 & $*$ & 3,180 \\
\hline \multirow[t]{2}{*}{ Total } & 15,244 & 3,510 & 28,010 & 4,818 & 12,667 \\
\hline & \multicolumn{5}{|c|}{ Total Milk Sales (Special-Milk-Program Milk Vended) } \\
\hline $\begin{array}{l}1956 \\
\text { Feb. }\end{array}$ & 2,350 & $* *$ & $* *$ & 2,859 & $* *$ \\
\hline Whar. & 2,050 & 459 & $* *$ & 2,630 & $* *$ \\
\hline Apr. & 1,794 & 169 & $* *$ & 2,573 & ** \\
\hline May & 1,440 & 125 & 5,970 & $2, \pm 75$ & ** \\
\hline Sept. & 1,362 & 276 & 5,683 & $* *$ & 3,626 \\
\hline Oct. & 1,764 & 505 & 8,354 & ** & 4,537 \\
\hline Nov. & 981 & 263 & 6,276 & $* *$ & 3,477 \\
\hline Dec. & 775 & 154 & 4,547 & ** & 2,257 \\
\hline $\begin{array}{l}1957 \\
\text { Jan. }\end{array}$ & 1,215 & $1+4$ & 6,576 & $* *$ & 3,525 \\
\hline Total & 13,731 & 2,095 & 37,406 & 10,537 & 17,422 \\
\hline
\end{tabular}

Total five schools, before vending- $64,2+9$ one-half pints.

Total five schools, Special-Milk-Program milk vended-81,191 one-half pints.

*Data not used because vending was not in use for the corresponding month a year later.

**Vending not used.

The test was run during morning recess periods. The first four grades, with an enrollment of 69 , had a 15 -minute recess beginning at 10:15 A.M. This was followed immediately by a 15 -minute recess period for grades five through eight. These upper grades had a total enrollment of 56. To insure that maximum use would be made of the machine during the test, students and teachers were provided nickels with which to purchase milk.

During the 30-minute period of the test the machine vended 145 one-half pints of chocolate milk. Sixteen students purchased more than one-hali pint. It required all but four minutes of this period to vend the 
milk, and children who waited to purchase milk had only a limited time for other activities during the recess period. Sales in other schools studied indicate that sales at this maximum rate are not likely to occur, but should they develop could be handled by adding additional machines.

During October 1957, this same school reported 2,136 one-half-pints of homogenized milk used with its school lunches (not vended) and 2,127 one-half pints of chocolate milk vended through the machine. Although the vending machine used was capable of vending three separate products at the same price, the one-cent tax on chocolate milk in West Virginia made the machine impractical for multiple product use. ${ }^{*}$

In another elementary school an earlier test had been run with a semi-automatic machine. 'This machine also had been in use at the school several weeks prior to the test. During one 15 -minute recess period students in grades one and two had the opportunity to obtain homogenized milk for three cents per one-half pint from the machine. To insure maximum use of the machine students were provided with one cent coins to use during the test. Only thirty units of milk were vended during this one recess period, and in order to accomplish this, both students from a higher grade and a teacher assisted the first and second graders to obtain milk (Figure 11).

${ }^{\ddagger}$ See page 38 for discussion of students' preference for chocolate milk.

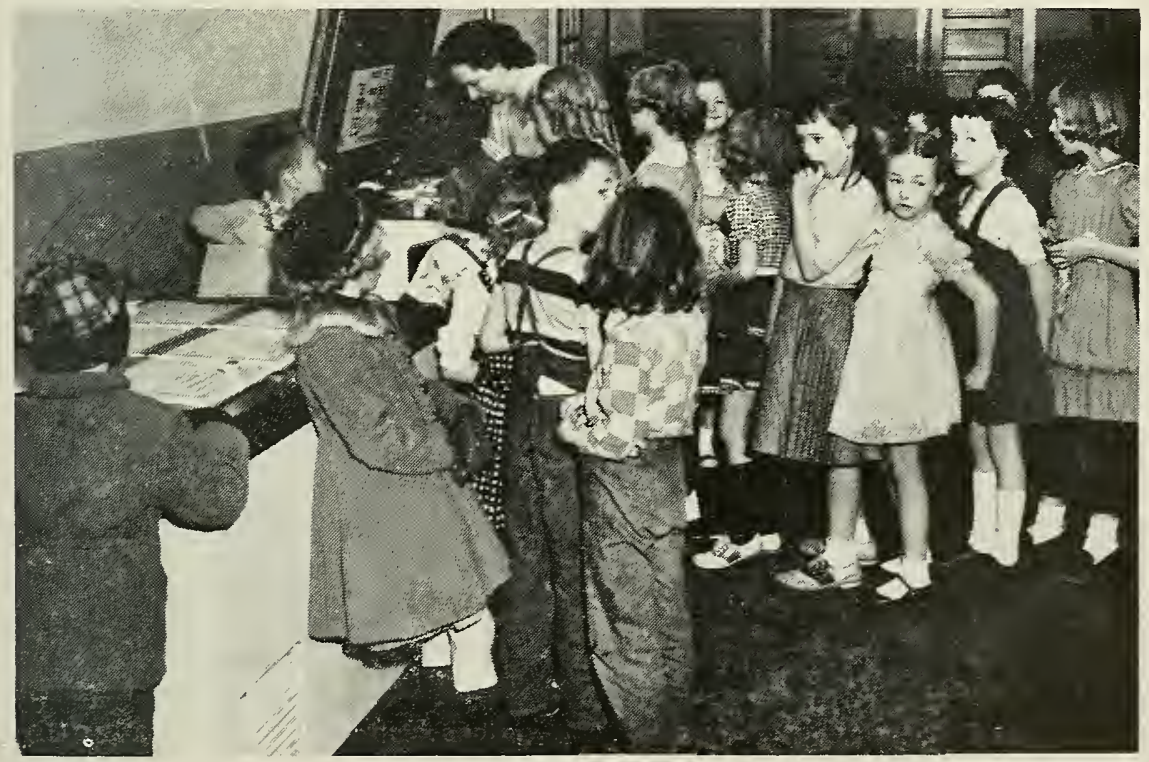

FIGURE 11. Semi-automatic vending machine in use in elementary school. Small children required assistance of teacher and older students to vend. Speed of vending was slow. 


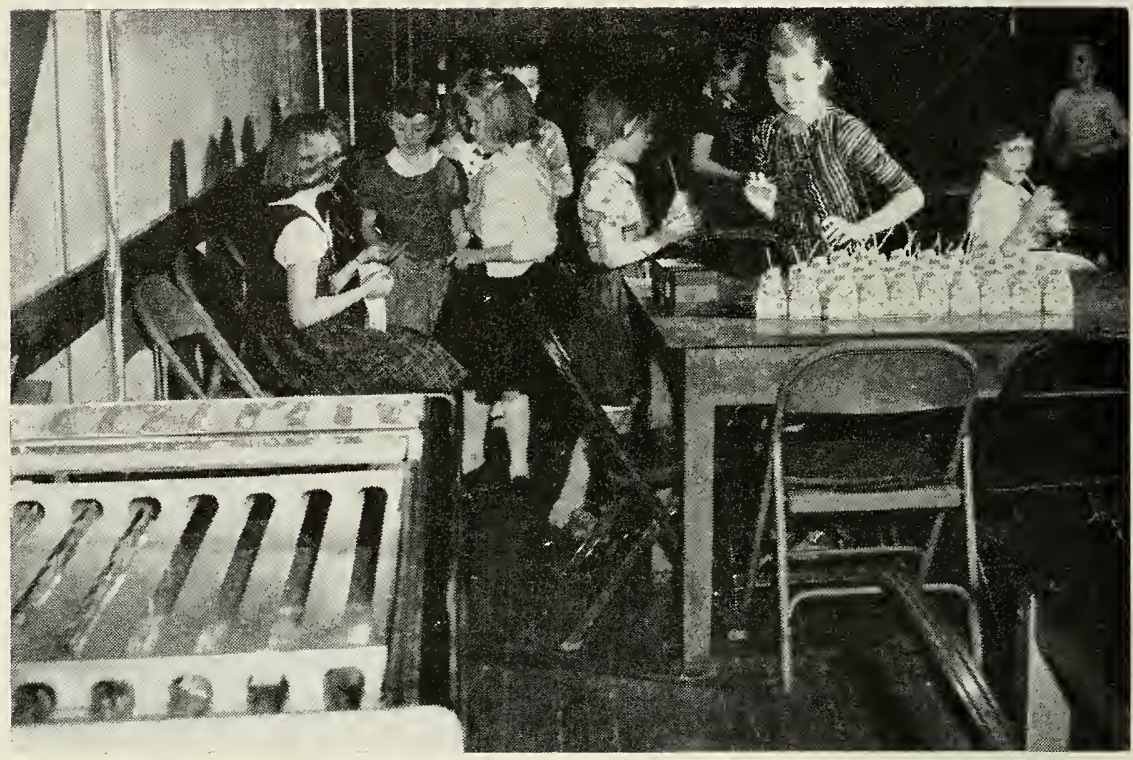

FIGURE 12. Semi-automatic vending machine was used as refrigerated storage in this school. Older students speeded sales to first grade students by collecting payment, opening cartons, and handing them to students.

At two other elementary schools using semi-automatic machines, the machines were used as refrigerated storages instead of as vendors. In one school about 10 minutes prior to the beginning of the recess period, two students from the sixth grade opened the machine, removed the amount of milk it was estimated could be sold, opened each container, and supplied a straw for it. When the recess started, one of the older children collected three cents from each younger child who desired milk, and the other passed milk out to the children in the first two grades (Figure 12). This practice was much faster than the vending observed in the school where the semi-automatic machine had been used for vending, and more children used milk. However, students in the school using the semi-automatic machine for vending also had an opportunity to purchase ice cream bars and cups .

In addition to their difficulty in operating semi-automatic machines many of the students in the first two grades had difficulty in opening certain types of paper cartons obtained from the machines. As pointed out above, these beginning students often were provided help in connection with the Special Milk Program in the schools. Apparently a larger proportion of the younger children than of the older children bought milk, and therefore their difficulties in using vending machines 
are important. Other studies also indicate that a larger proportion of children in the lower age groups drink milk. ${ }^{5}$

\section{Outdoor}

Outdoor vending, on a very limited scale, also was observed during the study. One dairy installed a large outdoor automatic machine in a residential area adjacent to the dairy's processing plant. This machine sold homogenized milk in both quart and one-half gallon paper cartons. Since about twice as many quarts as one-half gallows were sold, the volumes of milk sales from the two types of cartons were approximately equal. Sales through this machine, although never high, did not show the pronounced downward trend of many of the machines in plants and offices. Sales through this outdoor machine were only 17 percent lower in April, May, and June 1957 than during April, May, and June 1956. It had been installed on March 18, 1956.

The prices charged for milk through this machine were, at first, the same as the retail store price of homogenized milk, namely 24 cents per quart and 47 cents per half-gallon (Figure 13). Later, to facilitate changemaking required in vending, the price for vended milk in this machine was changed to 25 cents per quart and 50 cents per half-gallon, while other retail prices remained unchanged. This eliminated the necessity for the customer to carry numerous coins or to pay more than the quoted price for the vended milk. ${ }^{6}$ The increase in price had no noticeable effect on sales through the machine. Apparently the limited number of customers who used the machine tended to continue to use it rather regularly. A peak in sales occurred during December 1956, and may be attributed to the availability of milk twenty-four hours a day during the holiday period. This peak, however, was only 14 percent above the April to June average for the same year.

Undoubtedly better locations for machines of this type exist. In this study the milk distributors were not interested in further expansion of outdoor vending since some of their wholesale outlets objected to this competition and distributors feared the loss of wholesale accounts if further installations of outcloor vending machines for quarts and one-half gallons were made. One of the distributors in the Berkeley County area installed a number of outdoor machines in a nearby market where he was trying to establish sales and had few wholesale accounts to lose.

The volume of sales from this large outdoor machine in its existing location did not cover its fixed and operating costs. However, the milk

"What Makes the Market for Dairy Products, Bulletin 477, Wisconsin Agricultural Experiment Station, Madison; Wisconsin, September 1958, p. 17.

${ }^{6}$ The mechanism would deliver milk if the value of the coins inserted exceeded the quoted price but would not give change. 


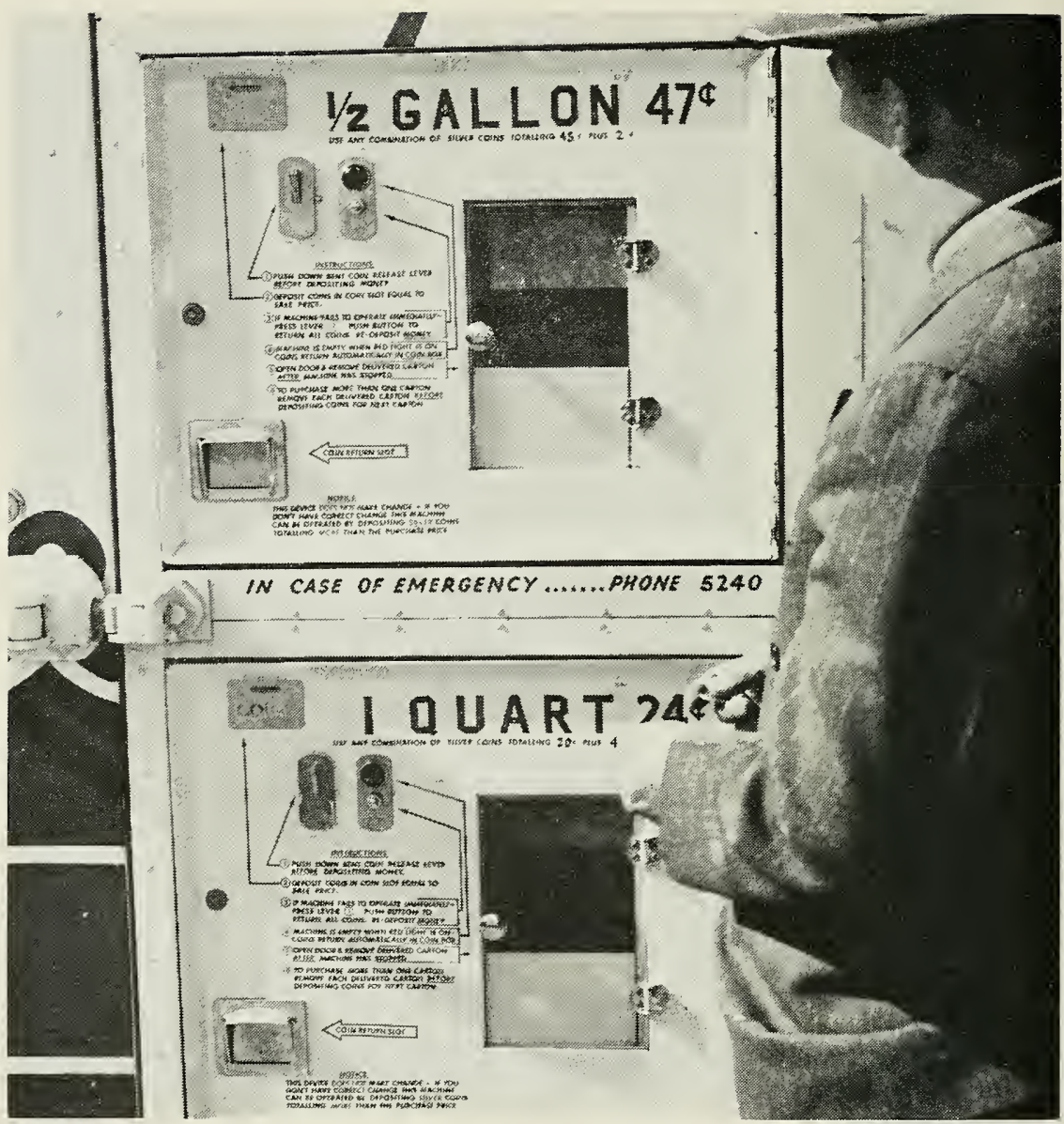

FIGURE 13. Vending milk at other than round number prices requires customer change and detailed instructions. Increasing prices from 24 to 25 cents per quart and from 47 to 50 cents per half-gallon had no noticeable effect on sales.

distributor purchased the machine from the manufacturer and considers it worthwhile because of its advertising value and because customers always find milk available at his dairy.

Two other one-half pint automatic vending machines were tried in two outdoor locations near U. S. Route 11, a well-traveled north-tosouth highway in the Shenandoah Valley. The first was tried at a fruit stand during the period August 17 to October 31, 1956. The second was placed outside a roadside soft-ice-milk stand during the period May 6 to June 30, 1957. Neither of these locations provided the sales volume necessary to justify their economic operation and the machines were removed following the brief periods of use indicated above. 


\section{PREFERENCES FOR PRODUCTS VENDED}

\section{Industrial Plants and Offices}

Chocolate milk or drink, orange drink (non-carbonated), buttermilk, and homogenized milk were offered to workers in plants and offices. Not all offerings were made over the entire period of the study nor through machines at all locations. (See Figures 2 to 8.) Periods when offerings of the several products were not made simultaneously have been eliminated from this part of the analysis.

When only chocolate milk or clrink and homogenized milk were offered, the ratio of chocolate to homogenized was 2.4 to 1.0 in fifteen locations covering in total 119 monthly records. However, the ratios varied from 0.7 chocolate to 1.0 homogenized in one location to 19.5 chocolate to 1.0 homogenized in another location. During the period studied homogenized milk sales through the vending machines exceeded chocolate milk sales at only one location; this was in a bakery where pints of homogenized and chocolate milk were vended at a price of 15 cents each.

When chocolate milk or drink, orange drink, and homogenized milk were all offered through the machines in fifteen locations, covering in total, 103 monthly records, the ratios were as follows: 2.3 chocolate, 0.8 orange, and 1.0 homogenized milk. Increased orange drink sales apparently were more closely associated with warm weather than sales of either chocolate milk or homogenized milk. The lower ratio for orange drink was due, in part, to the fact that this product was offered over a relatively extended period each year in some of the low-volume locations. Also, at some of the high-volume locations, orange drink was eliminated during periods when sales of chocolate milk were so high that it was expedient to use more than one section of the vending machines for chocolate.

Chocolate milk or clink, buttermilk, and homogenized milk were offered at five locations, covering in total 61 monthly records. At these locations the ratios were 2.6 chocolate, 0.3 buttermilk, and 1.0 homogenized.

The demand for chocolate milk exceeded the demand for the other vended milk products in nearly all plant and office locations. However, chocolate milk or drink was less profitable for milk distributors and vending operators because it sold at the same price as buttermilk and homogenized milk, yet was assessed a one-cent solt drink tax which did not apply to the other vended milk products. Orange drink was sold at the same price as chocolate milk but it, too, had the soft drink tax assessment of one cent per one-half pint, or pint. 


\section{Schools}

Only homogenized milk was vended in four of the schools studied. At one combined elementary and junior high school both chocolate and homogenized milk were vended. Chocolate milk was vended at five cents per one-half pint and homogenized milk at three cents per one-half pint, both in automatic machines placed side by side in the school lunch room.; The ratio of chocolate milk sales to homogenized milk sales at this school was 15.6 to 1.0 even though the chocolate milk was 67 percent higher in price. This school also had a School Lunch Program under which each pupil served was provided one-half pint of homogenized milk with his lunch. Total sales of milk at this school, including the homogenized milk provided with the lunches, showed a ratio of 0.9 chocolate milk to 1.0 of homogenized milk. Total sales of milk at the school were 37.5 percent higher during the first five months after the installation of the vending machines than during the corresponding period a year earlier. After the installation of the vending machines, milk sales averaged 21.8 percent higher during the school year than during the preceding school year. However, attendance was 11.3 percent higher at this school during the year the vending machines were in operation than during the preceding school year.

\section{Milk Compared with Competing Products}

Data were obtained to compare vended milk $^{8}$ sales with vended hot drinks, ${ }^{9}$ cold drinks, ${ }^{10}$ and candy ${ }^{11}$ for a 16 -month period during the course of the study. Vending of the above products was introduced almost simultaneously at three locations in a large industrial plant (Figure 14). Milk and hot drinks were sold at 10 cents per unit, while cold drinks and candy were vended at five cents per unit. Milk sales declined during much of the period but showed a slight upward tendency toward the end of the period (Figure 15). Hot drink sales showed a rising trend during the first nine months of the period and turned downward thereafter. Cold drink sales declined during the first half of the period, and following this, rose irregularly. Candy sales varied irregularly during the first half of the period and then trended downward.

In this plant, the decline in the sale of milk and other products sold through vending machines was not attributed to declines in either the number of employees or the hours worked per week. During the period

${ }^{7}$ It was necessary to use two machines in order to vend at the different prices which were necessitated by the soft drink tax on chocolate milk. At the time and with the machines available, it was not mechanically possible to vend at four cents per one-half pint.

"Includes chocolate drink, homogenized milk, and bnttermilk.

Includes coffee, hot cholocate, and soup.

"Includes cola and orange either carbonated or non-carbonated.

"Includes candy, chewing gum, mints, cookies, and cracker-peanut butter sandwiches. 


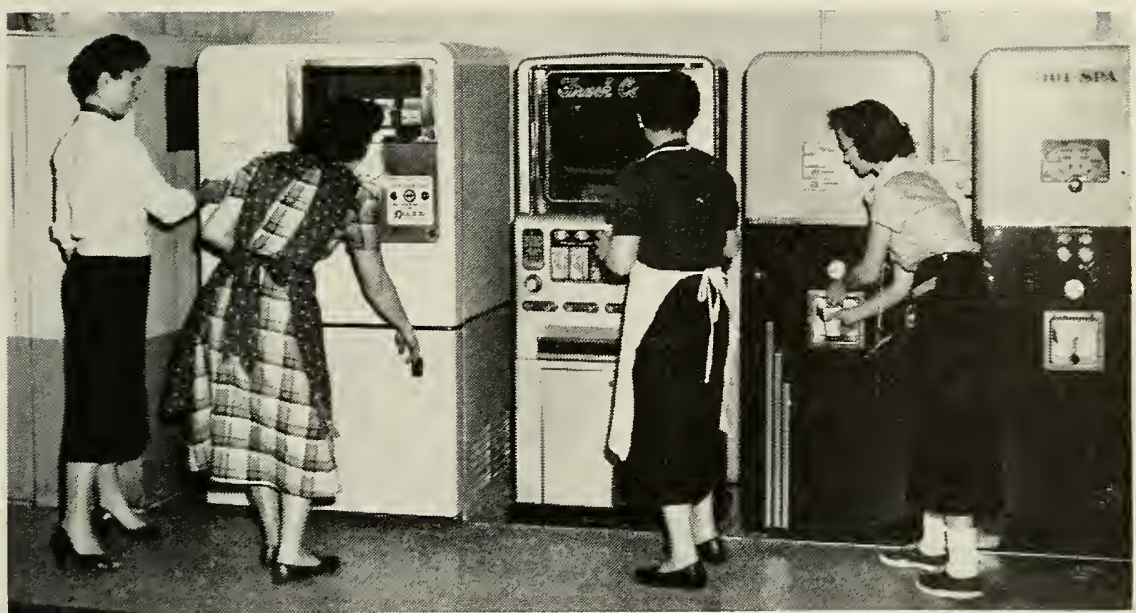

FIGURE 14. Milk, candy, hot drinks, and cold drinks were available to customers in machines grouped at convenient points throughout this plant.

of the study, the number of employees increased slightly and the hours worked per employee, per week, were above or equal to the mean for the period as often as they were below the mean (see Figure 16). In all cases, the percentage variations were small.

Unit sales of each item each month expressed as a percentage of all unit sales during the same month are shown in Figure 17. The five-cent items accounted for a larger percentage of unit sales than did the tencent items. A decrease in soft drink sales in the winter months seemed to be offset, in part, by candy sales. During the early part of the period, hot drink sales increased as milk sales declined. Toward the end of the period, milk sales were rising while hot drink sales were falling slightly. Gross sales revenue from milk was lower than from the competing products during most of the period considered.

\section{Employees' Attitudes Toward Milk Vending Machines SURVEY RESULTS}

This phase of the study was designed to obtain information on (1) the incidence and frequency of use of the milk vending machines, (2) the effect on milk vending of competition from other beverage vending machines, (3) employee satisfactions and dissatisfactions with the vending of inilk by machine, and (4) reasons for nonuse of the machines.

\section{Employee Use of Milk Vending Machines}

Results of the survey indicate that in the month preceding the interview, 63 percent of the employees in the plants being studied had bought 


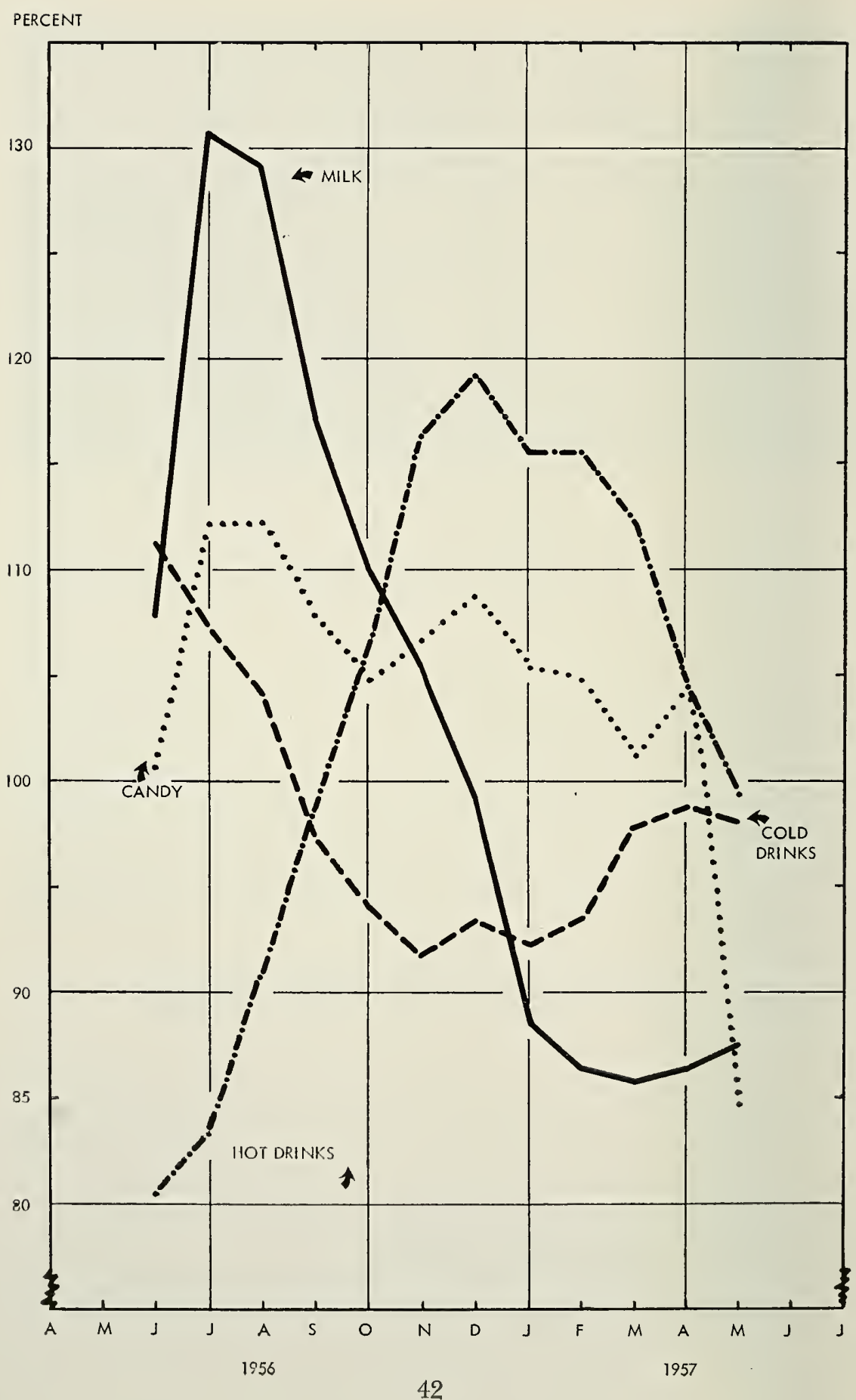


110

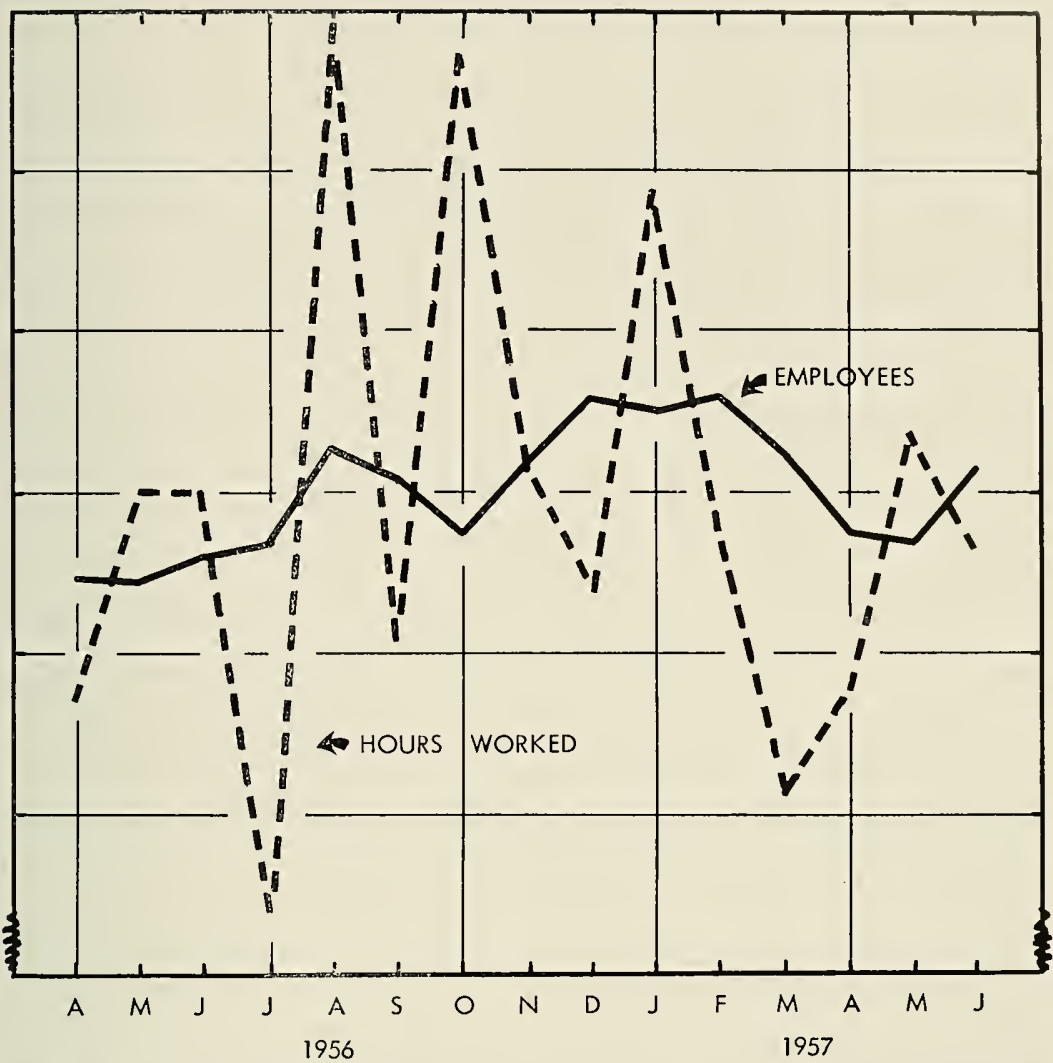

FIGURE 16. Number of employees and hours worked per week, industrial plant, Berkeley County, West Virginia, April 1956 to June 1957. (Number of employees per month and average hours worked per week for pay periods nearest the fifteenth of each month expressed as a percentage of the mean of the respective item for the entire period.)

milk from the vending machines during working hours. Of these employecs: four in ten had used the machines one or more times a day; thee in ten had used them at least once a week but not every day; three in ten hat used them less often han once a week. Before the installation of the machines there wats no milk avaliable at ten of the 12 plants, and only 1!) percent of the plant employees were in the habit of bringing milk in to drink while at work.

FIGURE 15. Milk, candy, cold drink, and hot drink sales through vending machines at three locations in an industrial plant, Berkeley County, West Virginia. (Monthly unit sales of each item expressed as a percentage of average unit sales of same item for the period April 1956 to July 1957. Data smoothed by five-month moving averages.) 


\section{-PERCENT}

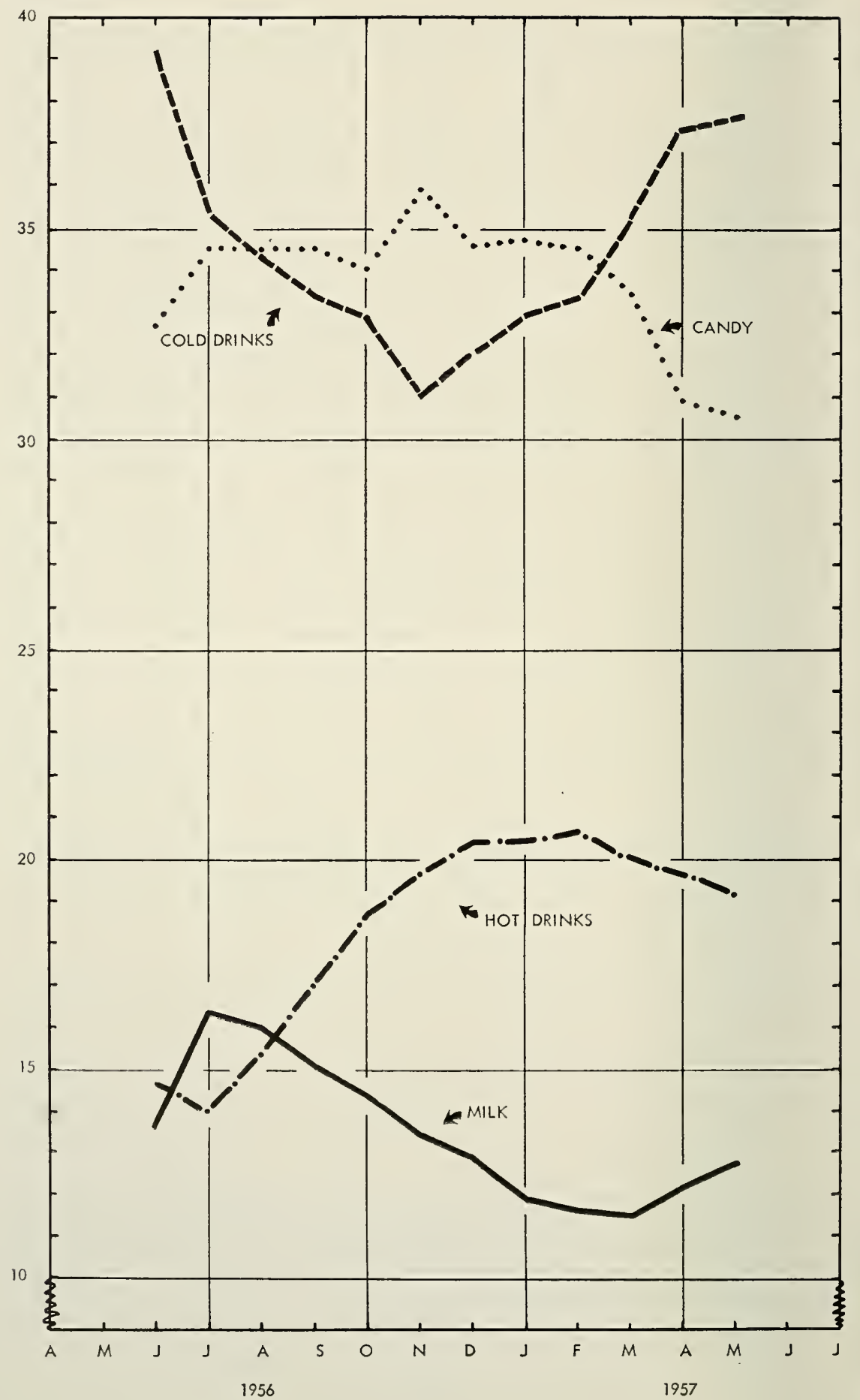


It was determined after the installation of the machines that both the proportion of employees drinking milk and the frequency with which they drank it while at work were associated with several employee characteristics. Younger people, workers on the night shift, and those doing strenuous work were more likely than others to use the vending machines. Incidence and frequency of use, however, were about the same for both men and women (Appendix Tables 1 and 3).

Ninety-two percent of the habitual milk drinkers bought vended milk for between-meal snacks. Of these, 41 percent reported that they drank milk between meals "regularly" and 59 percent did so "once in a while."

Milk was also drunk with lunch by a number of employees. Only one of the 12 plants in the study provided any in-plant feeding facilities other than vending machines, and many of the plants have no conveniently located eating places near by. Consequently, nearly 30 percent of the employees bring lunches to work with them, and of these, 42 percent drink milk from the machines at lunch time.

\section{Competition from Other Beverage Vending Machines}

In most of the plants where this study was made the milk vending machines were in competition with other beverage vending machines. Eleven of the 12 plants had soft drink vending machines, and three had coffee vending machines. In the plants having soft drink vending machines: 52 percent of the employees drank both milk and soft drinks; 22 percent drank only soft drinks; 11 percent drank only milk; and 15 percent drank neither beverage.

The 74 percent of the employees who used the soft drink machines used them more frequently than milk drinkers used the milk vending machines; about five employees in ten bought soft drinks one or more times a day in the month preceding the interview.

In plants having coffee vending machines: 31 percent of the employees drank both milk and coffee; 31 percent drank only milk; 17 percent drank only coffee; and 21 percent drank neither beverage.

In these plants about six coffee drinkers in ten used these coffee vending machines one or more times a day in the month preceding the interview. A more exact measure of the competitive effect of the coffee machines is provided by a comparison of milk consumption rates in

FIGURE 17. Milk, candy, cold drink, and hot drink sales through vending machines at three locations in an industrial plant, Berkeley County, West Virginia. (Monthly unit sales of each item expressed as a percentage of monthly total unit sales of all items for the period April 1956 to July 1957. Data smoothed by five-month moving average.) 
plants with and without such machines. In plants with coffee vending machines, 62 percent of the employees drank milk compared with 67 percent who drank milk in the plants where no coffee machines were available. The per capita consumption of milk was nearly 25 percent lower in plants where coffee as well as milk was available (Appendix Tables 6 and 7 ).

\section{Employee Dissatisfactions with Milk Vending Machines}

Results of the study indicate that the possibility of expanding consumption of milk by means of vencling machines is not limited by adverse attitudes toward the machines as such or by any inconvenience associated with their use. There were some complaints, however, about the servicing and operation of the machines. Six respondents in ten expressed dissatisfaction with the machines for reasons of this kind.

For example, respondents in all of the plants complained because the machines were allowed to run out of milk. Fifty-six percent of the milk drinkers reported that they had found the machines empty, and more than a third of those who made this complaint said that it happened one or more times a week.

Another source of chissatisfaction, expressed by about 10 percent of the respondents in nine of the 12 plants, was that occasionally milk from the vending machines was not fresh. In plants where this complaint was made the per capita consumption rate was only half as high as it was in plants where the complaint was not made.

The association between consumption and the feeling that milk from the machines was not fresh may be interpreted in two ways. Employees who believed the milk was not always fresh may have been less likely to use it, or, in plants where consumption rates were low, some milk may have remained in the machines long enough to lose its freshness. Although the suppliers were supposed to make frequent deliveries and to place the new supply so that any milk left over from a previous delivery rould be used first, no control over this factor was feasible. (See Figure 18.)

The third source of dissatisfaction, expressed by about 10 percent of the employees in seven plants, was that milk from the machines wats not always as cold as they liked it to be. This complaint was made in most of the plants where dissatislation was expressed about the freshness of the milk, but only seven respondents made both complaints.

Again, the consumption rate was considerably lower in plants where complaints about coldness were made than it was in plants where the complaint was not made. This relationship is more logical than the one previously clescribed since it is reasonable to suppose that the use rate 


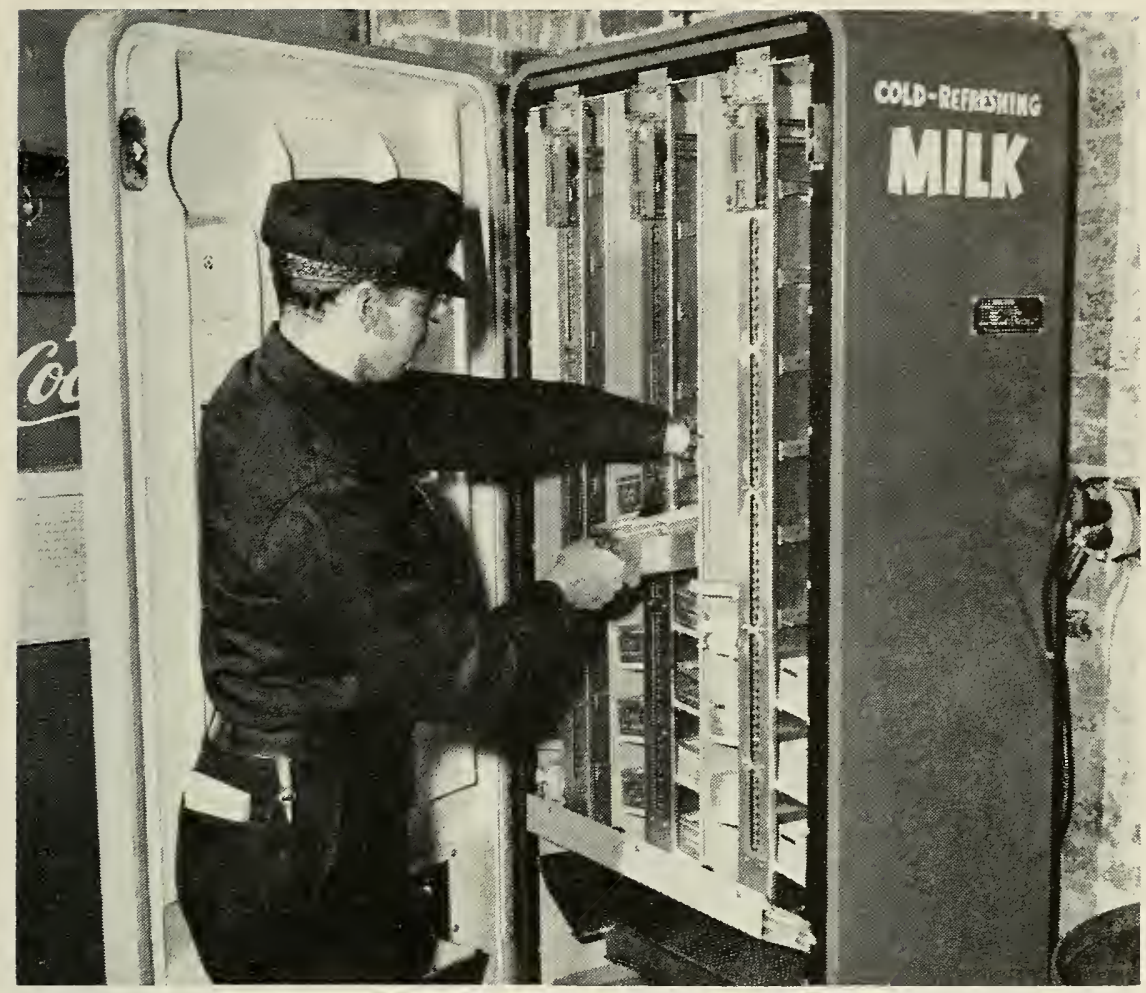

FIGURE 18. Vending machines were loaded so that the milk which had been in the machine for the greatest length of time would be used first.

would be lower in plants where consumers were dissatisfied with the coldness of the milk, whereas it is unlikely that remaining in the machine would make the milk warmer.

The three complaints just described were made in response to direct questions on each topic. A more general question was asked toward the close of the interview to give respondents an opportunity to express any dissatisfactions which had not been anticipated in planning the study. Respondents who drank milk were asked, "Is there anything you don't like about getting milk from the vending machine?" Eighty-six percent said there was nothing they disliked. Of those who did volunteer additional criticism: 41 percent said the machine was sometimes out of order or gave the wrong change; 24 percent said milk from the machines was too expensive; and 19 percent expressed a dislike of wax in the milk. No other complaints were offered with any significant frequency.

None of these criticisms from milk drinkers reflects any dissatisfaction inherent in vending as such. Among nonusers of the milk vend- 
ing machines, reasons for nonuse also were unrelated to vending as such. Of those who did not use the machines:

61 percent did not drink milk at all

11 percent limited their consumption of milk for health reasons

5 percent said they had enough milk at home

5 percent preferred other beverages

3 percent said the location of the machine was not convenient

1 percent said milk from the machine was too expensive

1 percent said the machine was not always in order

l per cent said the milk was not always fresh

11 percent gave miscellaneous reasons for nonuse

1 percent-the reason was not ascertained

\section{Management Reactions to Vending Machines}

Successful use of vending maclines in increasing milk consumption depends not only on employee acceptance but also upon favorable attitudes on the part of management and their willingness to permit the installation of the machines in their plants. Obtaining these concessions from managers is not always easy. Some believe that the machines may encourage interruptions in work schedules, that the machines may create unsightly or unsanitary conditions around the installation, or that securing satisfactory service and maintenance may be a problem.

Most of the managers of the plants in this study, however, expressed favorable attitudes toward the installations. Eleven of the 12 said they thought it was "a good thing" to have the machines in the plants, chiefly as an employee benefit. The one employer who was opposed to having the machine in his plant and who later had it removed resented the fact that his commission on milk sales was so small that he "never broke even on the electricity bill."

In spite of their generally favorable attitudes toward the machines, in response to specific questions several managers mentioned some of the same criticisms of the service and maintenance of the machines which their employees had mentioned. Three reported that the milk was left in the machines too long and sometimes became sour, and a fourth said that his employees had complained because a machine was out of order.

\section{Estimating Costs and Returns}

In milk vending, as in any business enterprise, fixed and variable costs must be paid before a profit can be obtained. Total variable costs, which increase as the number of units sold increases, are largely product costs but also include such items as payments for locations (including 
rental and electricity), consumers' sales taxes, and soft-drink taxes. Variable costs tend to be the same per unit sold, irrespective of the total volume of sales. Fixed costs, which include such items as depreciation, interest on investment, license fee, taxes, insurance, administrative expenses, and normal upkeep, decline per unit sold as the number of units increases. An operator can compute the point at which he can breakeven on his milk vending operations if he knows both costs and markups for all specified outputs.

This study has provided some but not all the information needed for these computations. All vending machines used in the Berkeley County area were new, and during the period of the study, required only minor repairs. Therefore it was impossible to determine the useful life of the machines. Nevertheless, from clata available, it is possible to make some estimates concerning returns and costs in plant and office locations. These are shown in Table 9.

At indoor locations, delivered prirchase prices of machines used in the study varied from $\$ 332.30$ for the semi-automatic types to $\$ 876.00$ for the most expensive, fully automatic machines. Annual depreciation, assuming a ten-year useful life and a salvage value of $\$ 25.00$, ranged from $\$ 30.73$ to $\$ 85.10$. Other fixed costs, not obtained in this study, would increase total fixed costs. Let us assume that the other fixed costs would equal the depreciation. The number of one-half pints of milk required annually to meet these costs would then range from 12,292 for each semiautomatic machine to 34,040 for each fully automatic machine if chocolate milk or drink and orange drink were vended. The range in sales

Table 9. Returns and Costs from Milk Vending, Office and Plant Locations, Berkeley County, West Virginia

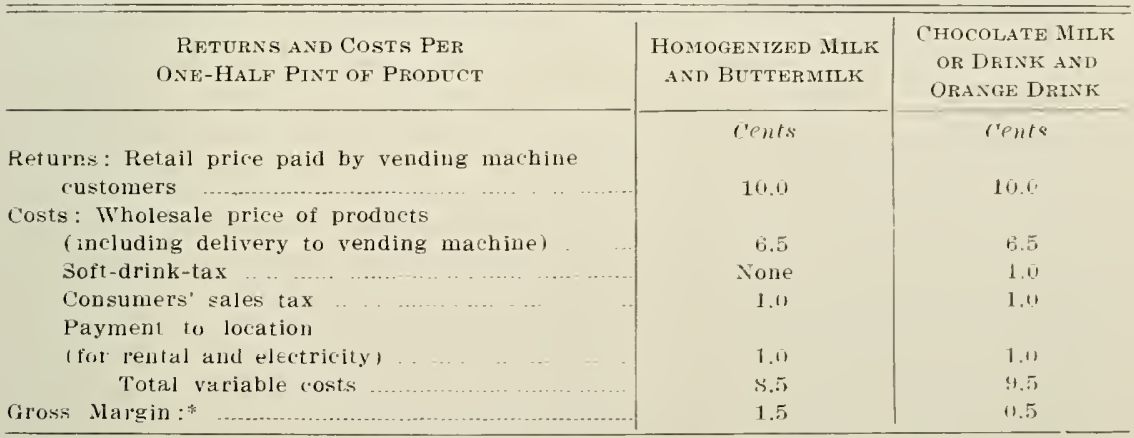

*This is the amount remaining to pay the fixed cost itens including depreciation, interest on investment, license fєes, taxes, insurance, administrative expenses, repairs and anv other expense items. $1 \mathrm{t}$ must also provide profits if any are to be realized. 
volumes would be from 4,097 units annually to 11,347 units if homoger. ized milk or buttermilk were vended.

The number of sales required to break even depends in part on the gross margin on each product and the ratios in which these products are sold at each location. The cost of the machines, their useful life, and costs for their maintenance also should be included. The latter will vary with the number of machines in use, with the distances between them, with the number of customers served, with the physical surroundings, and with other factors.

Some of the machines in this study dicl not have volumes of sales sufficient to meet the costs hypothesized above. In fact, within one year following the close of the experimental period, automatic machines at seven of the locations ( $\mathrm{A}, \mathrm{B}, \mathrm{J}, \mathrm{M}, \mathrm{N}, \mathrm{R}$, and $\mathrm{S}$ ) had been removed. Also, the machines at locations $G, P$, and $Q$ were out of use during that part of the year when the seasonal apple processing plants (in which they were located) were not in operation.

In some instances milk distributors operating a small number of vending machines were willing to keep them in operation even though they did not break even on returns as computed above. In some cases this was done for reasons of good will, competitive pressure, or to introduce products to new groups of consumers.

It may be necessary for location owners to forego location payment if sales volumes are low and if they want milk vending service for their employees or patrons. Otherwise, milk vending operators may not be able to break even at such locations.

\section{Obstacles to Milk Vending}

Among the obstacles to milk rending observed in this study were taxes on the product, licenses for machines, initial attitudes of plant managers and school officials torard rending, opposition to chocolate milk or drink, competitive relationships, and mechanical difficulties.

In West Virginia, a consumers' sales tax of one cent is collected on all sales of products which range between 6 cents and 50 cents in price. A special soft-drink tax of one cent per unit also is collected on each 16 fluid ounces or fraction thereof of flavored (chocolate) milk or drink. Thus, on a flavored milk or drink vended at a price of ten cents, a tax of two cents is included. This often leaves an insufficient margin above wholesale prices to justify the installation of milk vending machines, especially when it is anticipated that the number of units sold per machine will be low. 
At times, licenses also are burdensome. In West Virginia, there is an annual license fee of $\$ 5.50$ on each vending machine selling items priced at more than one cent per unit. Some cities in the State have an equal and additional license fee of the same amount. However, this city license was not applicable in Berkeley County. In addition, a license of $\$ 1.00$ annually is required for each vending machine to retail products. Another requirement for a permit of $\$ 1.00$ annually to retail soft-drink products was cancelled by the 1958 West Virginia Legislature. Processors and/or distributors of flavored milk or drink in the State are required to pay an annual license fee of $\$ 10.00$.

Attitudes of most school officials and plant managers were generally lavorable toward milk vending (see page 46). However, a few managers and school officials were not willing to have machines installed in their plants and schools. School officials often had additional administrative duties in connection with the various school lunch and milk programs. Several school principals, who already had school lunch programs in operation, indicated that milk vending was not desired for their schools. Several officials indicated that there was too little time between classes for milk consumption and that students were not permitted to roam around during study periods. Others believed that milk vending would add considerable work for custodial workers who already were overburdened.

Some school officials were opposed to chocolate milk sales in schools. Several milk distributors customarily produced chocolate drink rather than chocolate milk and were unwilling to add chocolate milk to their already long list of products. The Special Milk Program subsidized the consumption of regular, homogenized, and flavored (chocolate) milk but not flavored (chocolate) drink.

An obstacle pertaining to outdoor rending developed when the first machine was introduced into this market area. Some wholesale customers of the distributor introducing the machine objected and a few shifted their accounts to other distributors. This reflection of competition apparently was the major reason why no further installation of quart and one-half gallon vending machines were made in the market area. However, one distributor in the market installed several machines vending quarts and one-half pints in a nearby market which he was attempting to enter and therefore did not have to fear losing wholesale customers.

Mechanical difficulties were of minor consequence. Only one refrigeration mechanism failed during the course of the study and this occurred immediately after installation of the vending machine. Small children found some difficulty in operating the semi-automatic machines. There were no other serious mechanical obstacles. 


\section{Net Effect of Vending}

In this study, 72.5 percent of the milk vended was sold in machines in plants and offices. It was found that 63 percent of the employees using milk vending machines in these plants and offices purchased milk from the machines after they were installed, whereas, before the milk vending machines had been installed only 19 percent had brought milk in from the outside for consumption at work. Of those using machines, 92 percent consumed milk as a between-meal snack. Since the percentage of employees drinking milk at work after the installation of vending machines increased more than two-fold, it may be assumed that about twothirds of the milk vended in plants and offices represented a net gain.

In the Berkeley County market area, only 30 percent of the plant employees brought lunches for consumption at the plants where they worked. Only one of the plants studied had in-plant food service other than vending. Therefore, milk vending sales as great or greater than in the Berkeley County area should be expected in maket areas where a larger percentage of employees eat their lunches at work.

In this study, 17.9 percent of the milk vended was sold through five schools where vending machines were installed. No more than four schools used vended milk at any one time and no attempt was made to include in the study all schools in the market area. Enrollment of the five schools studied was only 30.9 percent of the total County enrollment during the 1956-57 school year. Inasmuch as total milk consumption at the schools studied was 26 percent greater after the introduction of vending machines (attendance increased only 7 percent) than before they were installed, more milk might be sold by this method if vending machines were available to a larger number of the students enrolled. Furthermore, the very great preference students showed for chocolate milk over homogenized milk, cren at a price 67 percent higher, indicates a still greater potential for total sales of milk through vending machines.

Only 10.2 percent of the milk vended in the Berkeley County area was sold through outdoor vending machines. However, the number of machines in use was very limited. It is not known whether outdoor rended milk represented an increase in total sales. Total sales of milk in the area trended upward slightly during the period of the study but estimated population and personal incomes also rose slightly. 


\section{APPENDIX}

\section{Technical Notes on the Employee Survey}

The sample of employees to be interviewed in this survey was designed to be representative of all employees in the plants being studied. A systematic sample was drawn from a complete list of employees provided by the management of each plant. As in all sample surveys, the results obtained may differ somewhat from the results which would have been obtained if a complete coverage had been made. Statistical techniques are, however, available for estimating the magnitude of these differences.

It is assumed that, although the sample was drawn systematically, the variances will approximate the variances that would have resulted from simple random sampling. ${ }^{1}$ Therefore, the formula used in computing the precision of sample estimates was

Where

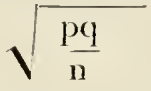

$p$ is the proportion of respondents who said they used the vending machines,

$\mathrm{q}$ is the proportion, who said they did not use them, and

$n$ is the number of employees in the sample.

As an example, survey results indicate that 63 percent of the employees bought milk from vending machines. The chances are about two out of three that this value is within 3 percent of the value that would have been obtained if all the employees had been interviewed.

When subgroups within the sample were being compared, the chisquare test was used. However, the interpretation of the survey results was in terms of practical rather than statistical significance.

${ }^{1}$ Hansen, M. H., Hurwitz, W. H., and Madow, W. G., Sample Survey Methods and Theory, John Wiley and Sons, New York, 1953. p. $503 \mathrm{ff}$. 
APPENDIX TABLE 1. Relationship Between Employee Characteristics and Use of Milk Vending Machines

\begin{tabular}{|c|c|c|c|c|}
\hline \multirow[b]{2}{*}{ CHARACTERISTICS } & \multicolumn{2}{|c|}{ EMPLOYEES WHO: } & \multirow[b]{2}{*}{ TOTAL } & \multirow[b]{2}{*}{ EMPLOYEES } \\
\hline & $\begin{array}{l}\text { USED MILK } \\
\text { VENDING } \\
\text { MACHINES }\end{array}$ & $\begin{array}{l}\text { DID NOT } \\
\text { USE MILK } \\
\text { VENDING } \\
\text { MACHINES }\end{array}$ & & \\
\hline & Percent & Percent & Percent & Number \\
\hline \multicolumn{5}{|l|}{$\mathrm{Age}^{*}$} \\
\hline Under 45 & 72 & 28 & 100 & 452 \\
\hline 45 and over & 49 & 51 & 100 & 285 \\
\hline \multicolumn{5}{|l|}{ Shift worked** } \\
\hline Day & 60 & 40 & 100 & 653 \\
\hline Night & 87 & 13 & 100 & 89 \\
\hline \multicolumn{5}{|l|}{ Strenuousness of work $* * *$} \\
\hline Light & 58 & 42 & 100 & 385 \\
\hline Heavy _... & 80 & 20 & 100 & 233 \\
\hline \multicolumn{5}{|l|}{ Sex } \\
\hline Male & 67 & 33 & 100 & 332 \\
\hline Female & 60 & 40 & 100 & 417 \\
\hline All respondents _...... & 63 & 37 & 100 & 749 \\
\hline
\end{tabular}

*Age was not ascertained for eight respondents.

**Shift worked was not ascertained for five respondents.

***:Strenousness of work was not ascertained for 62 respondents.

APPENDIX TABLE 2. Frequency of Use of Beverage Vending Machines in 12 Industrial Plants in Martinsburg, West Virginia

\begin{tabular}{|c|c|c|c|}
\hline \multirow[b]{2}{*}{ FREQUENCY } & \multicolumn{3}{|c|}{ EMPLOYEES WHO USED: } \\
\hline & $\begin{array}{c}\text { MILK } \\
\text { VENDING } \\
\text { MACHINES }\end{array}$ & $\begin{array}{c}\text { COFFEE } \\
\text { VENDING } \\
\text { MACHINES }\end{array}$ & $\begin{array}{l}\text { SOFT DRINK } \\
\text { VENDING } \\
\text { MACHINES }\end{array}$ \\
\hline & Percent & Percent & Percent \\
\hline One or more times a day & 42 & 58 & 53 \\
\hline $\begin{array}{l}\text { At least once a week but less often } \\
\text { than once a day }\end{array}$ & 28 & 32 & 32 \\
\hline Less often than once a week & 30 & 10 & 15 \\
\hline Total & 100 & 100 & 100 \\
\hline Number of employees & $467 *$ & $265 * *$ & 537 \\
\hline
\end{tabular}

*Frequency of use of milk vending machines was not ascertained for eight respondents.

**Frequency of use of coffee vending machines was not ascertained for six respondents. 


\section{APPENDIX TABLE 3. Relationship Between Employee Characteristics and Frequency of Use of Milk Vending Machines}

\begin{tabular}{|c|c|c|c|c|c|}
\hline \multirow[t]{2}{*}{ Characteristics } & \multicolumn{3}{|c|}{$\begin{array}{l}\text { EMPLOYEES WHO USED MILK } \\
\text { VENDING MACHINES }\end{array}$} & \multirow{2}{*}{ TOTAL } & \multirow[t]{2}{*}{ Employees } \\
\hline & Frequently & Moderately & Infrequently & & \\
\hline & Percent & Percent & Percent & Percent & Number \\
\hline \multicolumn{6}{|l|}{ Age* } \\
\hline Under 45 & 47 & 26 & 27 & 100 & 324 \\
\hline 45 and over & 30 & 33 & 37 & 100 & 135 \\
\hline \multicolumn{6}{|l|}{ Shift Work*** } \\
\hline Day & 40 & 28 & 32 & 100 & 386 \\
\hline Night & 54 & 25 & 21 & 100 & 76 \\
\hline \multicolumn{6}{|l|}{$\begin{array}{l}\text { Strenuousness of } \\
\text { Work*** }\end{array}$} \\
\hline Light & 30 & 30 & 40 & 100 & 222 \\
\hline Heavy & 57 & 25 & 18 & 100 & 183 \\
\hline \multicolumn{6}{|l|}{ Sex } \\
\hline Male & 46 & 27 & 27 & 100 & 218 \\
\hline Female & 39 & 28 & 33 & 100 & 249 \\
\hline
\end{tabular}

* Age was not ascertained for eight respondents.

**Shift worked was not ascertained for five respondents.

***Strenousness of work was indeterminate for 62 respondents

APPENDIX TABLE 4. Replies to the Questions, "Do You Drink Milk From the Vending Machines Between Meals?" and "Do You Do This Regularly Or Just Once In A While?"

\begin{tabular}{l|c|c}
\hline \hline \multicolumn{1}{c|}{ REPLIES } & \multicolumn{2}{|c}{ EMPLOYEES WHO: } \\
\cline { 2 - 3 } & $\begin{array}{c}\text { DRINK MILK } \\
\text { BETWEEN } \\
\text { MEALS }\end{array}$ & $\begin{array}{c}\text { DRANK MILK } \\
\text { FROM THE } \\
\text { VENDING } \\
\text { MACHINES }\end{array}$ \\
\hline $\begin{array}{l}\text { Yes, drank milk between meals } \\
\text { Regularly - }\end{array}$ & $\begin{array}{c}\text { Percent } \\
92\end{array}$ \\
$\begin{array}{l}\text { No, did not drink milk between meals } \\
\text { Total - }\end{array}$ & 51 & 8 \\
Number of employees & 100 & 100 \\
\end{tabular}


APPENDIX TABLE 5. Replies to the Questions, "Do You Usually Bring Your Lunch To Work With You, Go Out Of The Plant To Eat, Or Eat In The Plant Cafeteria?" and (Asked of Those Who Bring Their Lunches) "Do You Usually Drink Milk From The Vending Machine With Your Lunch?"

\begin{tabular}{c|c|c}
\hline \multicolumn{1}{c|}{ REPLIES } & $\begin{array}{c}\text { EMPLOYEES WHO: } \\
\text { DRANK MILK FROM } \\
\text { VENDING MACHINES } \\
\text { AND WHO BROUGHT } \\
\text { LUNCH TO WORK }\end{array}$ & $\begin{array}{c}\text { ALL } \\
\text { ERPLOYEES }\end{array}$ \\
\hline $\begin{array}{c}\text { Brought lunch } \\
\text { Drank milk from vending machines } \\
\text { with lunch }\end{array}$ & Percent & 28 \\
Did not drink milk from vending \\
machines with lunch
\end{tabular}

APPENDIX TABLE 6. Use of Milk Vending Machines in Plants with and Without Coffee Vending Machines

\begin{tabular}{c|c|c|c|c}
\hline \hline \multirow{2}{*}{ PLANTS } & \multicolumn{2}{|c|}{ EMPLOYEES WHO: } & & \\
\cline { 2 - 3 } & $\begin{array}{c}\text { USED MILK } \\
\text { VENDING } \\
\text { MACHINES }\end{array}$ & $\begin{array}{c}\text { DID NOT } \\
\text { USE MILK } \\
\text { VENDING } \\
\text { MACHINES }\end{array}$ & TOTAL & EMPLOYEES \\
\hline $\begin{array}{c}\text { WATh coffee vending } \\
\text { machines - }\end{array}$ & Percent & Percent & Percent & Number \\
$\begin{array}{c}\text { Without coffee vending } \\
\text { machines - }\end{array}$ & 67 & 38 & 100 & 550 \\
\hline
\end{tabular}

APPENDIX TABLE 7. Monthly Per Capita Consumption of Milk in Plants with and Without Coffee Vending Machines

\begin{tabular}{c|c|c}
\hline PLANTS & ALL PLANTS & $\begin{array}{c}\text { LARGEST PLANT } \\
\text { EXCLUDED }\end{array}$ \\
\hline With coffee vending machines --- & $1 / 2$ Pints & $1 / 2$ Pints \\
Without coffee vending machines & 3.6 & 3.7 \\
\hline
\end{tabular}


APPENDIX TABLE 10. Monthly Per Capita Consumption of Milk in Plants Where Complaints About Coldness of Milk from Vending Machines Were Made and Plants Where the Complaint Was Not Made

\begin{tabular}{l|c|c}
\hline PLANTS & $\begin{array}{c}\text { ALL } \\
\text { PLANTS }\end{array}$ & $\begin{array}{c}\text { LARGEST } \\
\text { PLANT } \\
\text { EXCLUDED }\end{array}$ \\
\hline Where complaints about coldness were not made & $1 / 2$ Pints & $1 / 2$ Pints \\
Where complaints about coldness were made & 5.2 & 5.2 \\
\hline
\end{tabular}

APPENDIX TABLE 11. Monthiy Per Capita Consumption of Milk in Plants Where Complaints Were Made About Freshness of Milk from Vending Machines and in Plants Where the Complaint Was Not Made

\begin{tabular}{c|c|c} 
PLANTS & $\begin{array}{c}\text { ALL } \\
\text { PLANTS }\end{array}$ & $\begin{array}{c}\text { LARGEST } \\
\text { PLANT } \\
\text { EXCLUDED }\end{array}$ \\
\hline $\begin{array}{c}\text { Where complaints about freshness of milk were } \\
\text { not made }\end{array}$ & $\begin{array}{c}1 / 2 \text { Pints } \\
\begin{array}{c}\text { Whe complaints about freshness of milk were } \\
\text { made }\end{array}\end{array}$ & 3.1 \\
\hline
\end{tabular}


